\title{
PREPARATION OF ACTIVATED CARBON FROM ION EXCHANGE RESIN WASTE AND ITS APPLICATION FOR MANGANESE REMOVAL FROM GROUNDWATER
}

\author{
A.A.Swelam ${ }^{1}$,Y.R.Gedamy ${ }^{2}$ and A.A Elshahed ${ }^{3}$ \\ Chemistry Department, Faculty of Science, Al-Azhar University, Cairo, Egypt. \\ 2 Hydrogeochemistry Dept., Desert Research Center, El-Matareya, Cairo, Egypt. \\ Author to whome Correspondence should be addressed: \\ E-Mail: yahiagedamy2014@yahoo.com_ahmedelshahed2018@gmail.com
}

\begin{abstract}
The present study aims to synthesize an activated carbon adsorbent (S-AC, P-AC and OH-AC) from polystyrene divinyl benzene waste under different carbonization temperature $\left(450{ }^{\circ} \mathrm{C}\right.$ and $900{ }^{\circ} \mathrm{C}$ and activation conditions $\left(\mathrm{H}_{2} \mathrm{SO} 4, \mathrm{H}_{3} \mathrm{PO}_{4}\right.$ or $\left.\mathrm{NaOH}\right)$. It being characterized and applied as an adsorbent for manganese removal from groundwater. FTIR results indicate that the changes in the peak intensities clear that the binding process was occurring on the surface of the adsorbent. Different factors such as solution $\mathrm{pH}$, adsorbent dosage, contact time, temperature and $\mathrm{Mn}$ (II) initial concentration were investigated. The results showed that manganese adsorption capacity decreases with the increase of the carbonization temperature $\left(900^{\circ} \mathrm{C}\right)$ and of activating agent $\mathrm{H}_{2} \mathrm{SO} 4>\mathrm{H}_{3} \mathrm{PO} 4>\mathrm{NaOH}$. Kinetically, it was shown that the activation temperature of $450^{\circ} \mathrm{C}$ is the best temperature for activating the adsorbent carbons. The pseudo-first-order model is appropriate for predicting the adsorption process of $\mathrm{Mn}(\mathrm{II})$ onto the $\mathrm{P}-\mathrm{AC} 450^{\circ} \mathrm{C}, \mathrm{P}-\mathrm{AC} 900^{\circ} \mathrm{C}$ and $\mathrm{OH}-\mathrm{AC} 900^{\circ} \mathrm{C}$, while the pseudo-secondorder model is appropriate for predicting the adsorption process of $\mathrm{Mn}(\mathrm{II})$ onto the both $\mathrm{S}-\mathrm{AC} 450^{\circ} \mathrm{C}, \mathrm{S}-\mathrm{AC}$ $900^{\circ} \mathrm{C}, \mathrm{OH}-\mathrm{AC} 450^{\circ} \mathrm{Cand} \mathrm{OH}-\mathrm{AC} 900^{\circ} \mathrm{C}$. Thermodynamic calculations affirmed that $\mathrm{Mn}$ (II) adsorption onto S$\mathrm{AC}$ and $\mathrm{P}-\mathrm{AC}$ was an endothermic process while onto $\mathrm{OH}-\mathrm{AC}$ was exothermic process. Finally, the results suggested that the prepared S-AC has high adsorption capacities for $\mathrm{Mn}(\mathrm{II})$ compared with other adsorbents, such as $\mathrm{P}-\mathrm{AC}$ and $\mathrm{OH}-\mathrm{AC}$. Therefore, $\mathrm{S}-\mathrm{AC} 450^{\circ} \mathrm{Ccan}$ be used in the groundwater treatment unit.
\end{abstract}

Keywords: Activated carbon; ion exchange resin; ground water.

\section{INTRODUCTION}

Manganese $(\mathrm{Mn})$ is abundant in the earth and exists as a component of more than 30 kinds of manganese oxides/hydroxide minerals. The presence of soluble manganese divalent ion $\mathrm{Mn}$ (II) is a salient feature in the groundwater [1].Manganese occurs naturally in surface water and groundwater, especially in oxygen depleted or anaerobic systems. The concentrations of manganese in groundwater are dependent upon a number of factors such as rainfall chemistry, aquifer lithology, geochemical environment and groundwater flow paths. Some of these factors can be highly variable over relatively small spatial and temporal scales. Manganese can be leached from overlying soils and minerals in underlying rocks as well as from the minerals of the aquifer itself. $\mathrm{Mn}$ (II) contaminated groundwater not only causes aesthetic and operational problems, such as water discoloration, laundry stains and pipes clogging, but also causes chronic poisoning to the human body and threats to the health [2]. The maximum contaminant level for manganese in drinking water has been established as $0.4 \mathrm{mg} / \mathrm{L}$ (WHO, 2011), [3].Therefore, effective removal of Mn(II) from the groundwater is necessary to provide safe drinking water.

In the developing countries, many water resources are polluted due to a diminished public awareness regarding environmental health, which leads to the indiscriminate disposal of waste or the discharge of effluent from industrial activity [4]. As the world population increases, there is an annual decline in the accessibility of clean and safe water, despite it being one of the most basic human necessities. More than half of a body's weight is composed of water, and it is important for cell growth, use as a body coolant, the protection of tissue from shock and damage, aiding in the digestion and absorption of food, 
the removal of waste and the maintenance of a healthy weight [5].

Polystyrene divinyle benzene was produced from petroleum derivatives, it can use for some plastic industries as yogurt cans and the waste of polystyrene divinyle benzene is generated in large amount which leads to an environmental problem.

The principal goal of water treatment is to minimize the risks from biological, chemical and physical by reducing them to acceptable levels. This includes ensuring that the water is of high aesthetic quality; that is, the taste, odor, clearness, and color of the water do not cause offense to consumers. This also means guaranteeing that the water's chemical constituents do not cause operational problems in circulation systems [6]. Various techniques have been employed for the mitigation of $\mathrm{Mn}$ (II) including those of coagulation/flocculation [7], ion exchange [8], oxidation/filtration [9], adsorption [10] and membrane filtration [11].Due to the advantages of low cost and environmental friendliness, adsorption has been preferred worldwide.

The present work aims to introduce an inexpensive and renewable adsorbent for $\mathrm{Mn}^{2+}$ removal by converting exhausted resin with no commercial value into a promising adsorbent with the aid of mineral acids $\left(\mathrm{H}_{2} \mathrm{SO}_{4}\right)$ (S-AC) and $\mathrm{H}_{3} \mathrm{PO}_{4}(\mathrm{P}-\mathrm{AC})$ and base $\mathrm{NaOH}$ $(\mathrm{OH}-\mathrm{AC})$ activation. The use of exhausted resin as renewable precursor for producing carbonaceous adsorbent materials in adsorption of $\mathrm{Mn}^{2+}$ from aqueous solutions and groundwater in the batch-model process will diminish the large amount of exhausted resin, reduce environmental complications and produce value-added products. The adsorption parameters, kinetic and thermodynamic studies were performed to explore and predict the adsorption of $\mathrm{Mn}^{2+}$ ions onto the activated carbon.

\section{EXPERIMENTAL}

\section{Reagents}

Sulfuric acid $\left(\mathrm{H}_{2} \mathrm{SO}_{4}\right)$, Phosphoric acid $\left(\mathrm{H}_{3} \mathrm{PO}_{4}\right)$, sodium hydroxide $(\mathrm{NaOH})$, hydrochloric $(\mathrm{HCl})$, and manganese chloride
$\left(\mathrm{MnCl}_{2}\right)$ were purchased from Sigma-Aldrich (St. Louis, MO, USA). Waste polystyrene ascation exchange resin (Amberjet 1500) was supplied by Beihua Chemical Building Materials Co., Ltd. (Hebei, China).

\section{Preparation of the carbon composites}

Polystyrene divinyl benzene obtained by polymerization of (styrene and divinyle benzene), the styrene $\left(\mathrm{C}_{8} \mathrm{H}_{8}\right)$ is polymerized with itself and with divinyle benzene $\left(\mathrm{C}_{10}\right.$ $\mathrm{H}_{10}$ ),prior to its use, the resin waste was successively rinsed with ethanol, $5 \% \mathrm{HCl}$ solution, $5 \% \mathrm{NaOH}$ solution, distilled water until the solution had a neutral $\mathrm{pH}$ to remove impurities, dried $60^{\circ} \mathrm{C}$ for $24 \mathrm{~h}$. Carbonization and activation were conducted in a horizontal cylindrical furnace $\left(450^{\circ} \mathrm{C}\right.$ or $\left.900^{\circ} \mathrm{C}\right)$ for $3 \mathrm{hrs}$ (Qianqian et al., 2014) [12], after cooling the obtained carbon was mixed with concentrated sulfuric acid, phosphoric acid and powdered sodium hydroxide separately at a mass ratio of 1:3. Subsequently, after cooling the obtained carbons (S-AC, P-AC and OHAC) was crushed and washed with distilled water until the solution had neutral $\mathrm{pH}$, dried under vacuum.

\section{Batch adsorption experiments}

Batch adsorption experiments were performed by shaking a mixture of a fixed amount of S-AC, P-AC and OH-AC separately with $25 \mathrm{ml}$ of manganese solution of a known concentration in a series of $100 \mathrm{ml}$ plastic bottles in a constant temperature shaker(Stuart CB302) for a known period of time. The suspensions were taken out at predetermined time intervals and centrifuged and analyzed using atomic absorption spectroscopy (SHIMADZUAA700). Several experiments were carried out with a variety of initial manganese concentrations, $\mathrm{pH}$, contact time, adsorbent dosage, and temperature respectively. The amount of adsorbate that adsorbed onto the carbon at time $\mathrm{t}, \mathrm{q}_{\mathrm{t}}(\mathrm{mg} / \mathrm{g})$ and removal $\%$ from aqueous solution or groundwater are calculated from Eqs.1 and 2,respectively.

$q_{e}=\frac{\left(\mathrm{C}_{0}-\mathrm{C}_{\mathrm{e}}\right) \mathrm{V}}{W \times 1000}$

The removal percentage yield $(\mathrm{R} \%)=$ 


\section{$\frac{\mathrm{C}_{0}-\mathrm{C}_{\mathrm{e}}}{C_{0}} \times 100$}

Where, $\mathrm{C}_{\mathrm{o}}$ is the initial $\mathrm{Mn}^{2+}$ ion concentration $(\mathrm{mg} / \mathrm{L})$ at equilibrium, $\mathrm{Ce}$ is the concentration of $\mathrm{Mn}^{2+}$ at any time $\mathrm{t}, \mathrm{V}$ is the volume of the manganese solution and $\mathrm{w}$ is the weight of carbon in $(\mathrm{g})$. All experimental measurements were within $\pm 0.1 \%$ accuracy.

\section{RESULTS AND DISCUSSION}

\section{Characterization of the synthesized carbons}

To check about the structure of the new activated carbon before and after synthesized, a characterization must be done as the determination of the functional groups by FTIR. To better understand the differences among modified activated carbon produced by different modifiers, FTIR analysis was performed to identify surface functional groups on the carbon surfaces. Fig.(1) shows the FTIR of the activated carbon at $450^{\circ} \mathrm{C}(\mathrm{AC})$. The spectrum show a relatively strong band at $1573.91 \mathrm{~cm}^{-1}$ due to combined stretching vibrations of conjugated $\mathrm{C}=\mathrm{O}$ group and aromatic rings [13]. The thermal activated carbon obtained at $450^{\circ} \mathrm{C}$ shows a small peak at $1697.36 \mathrm{~cm}^{-1}$ characteristic of the $\mathrm{C}=\mathrm{O}$ stretching vibration. The small intensity of this peak suggests a relatively low content of carboxylic groups as compared to other oxygen groups of carbon [14].Weak absorption band in all spectra at about $3047.53 \mathrm{~cm}^{-1}$ is ascribed to aromatic $\mathrm{C}-\mathrm{H}$ stretching vibrations.

The FTIR spectrum of the S-AC (Fig.2) shows a band at $3433.29 \mathrm{~cm}^{-1}$ assigned to $\mathrm{OH}^{-}$ stretching vibration. This finding is apparently due to the fact that $\mathrm{H}_{2} \mathrm{SO}_{4}$ initiated bond cleavage, leading to dehydration and elimination reactions that release volatile products such as water, acid, alcohol and other chemical substances. This is followed by partially aromatic city and re-combination of species to form a stronger cross-linked solid. In other words, $\mathrm{H}_{2} \mathrm{SO}_{4}$ breaks many bonds in aliphatic and aromatic species existed in the precursor material leading to liberation and elimination of many light and volatile substances causing partial aromatization and thus carbonization. In addition, if the spectrum of the modified activated carbon- $\mathrm{H}_{2} \mathrm{SO}_{4}$ is compared with activated carbon by means of sulfur related absorption bands, it is seen that $1165 \mathrm{~cm}^{-1}$ and new absorption bands appeared in the spectrum of S-AC sample at around $1072.42-1010.7 \mathrm{~cm}^{-1}$ assigned to asymmetric and symmetric stretching vibration of $\mathrm{SO}_{2}$, respectively confirming the presence of surface $\mathrm{SO}_{2}$ complexes [15 and 16]. However, the bands at $1010.7 \mathrm{~cm}^{-1}$ (C-O stretching in phenols, alcohols) and $\mathrm{H}_{2} \mathrm{SO}_{4}$ acid $\left(-\mathrm{SO}_{3}\right.$ groups).

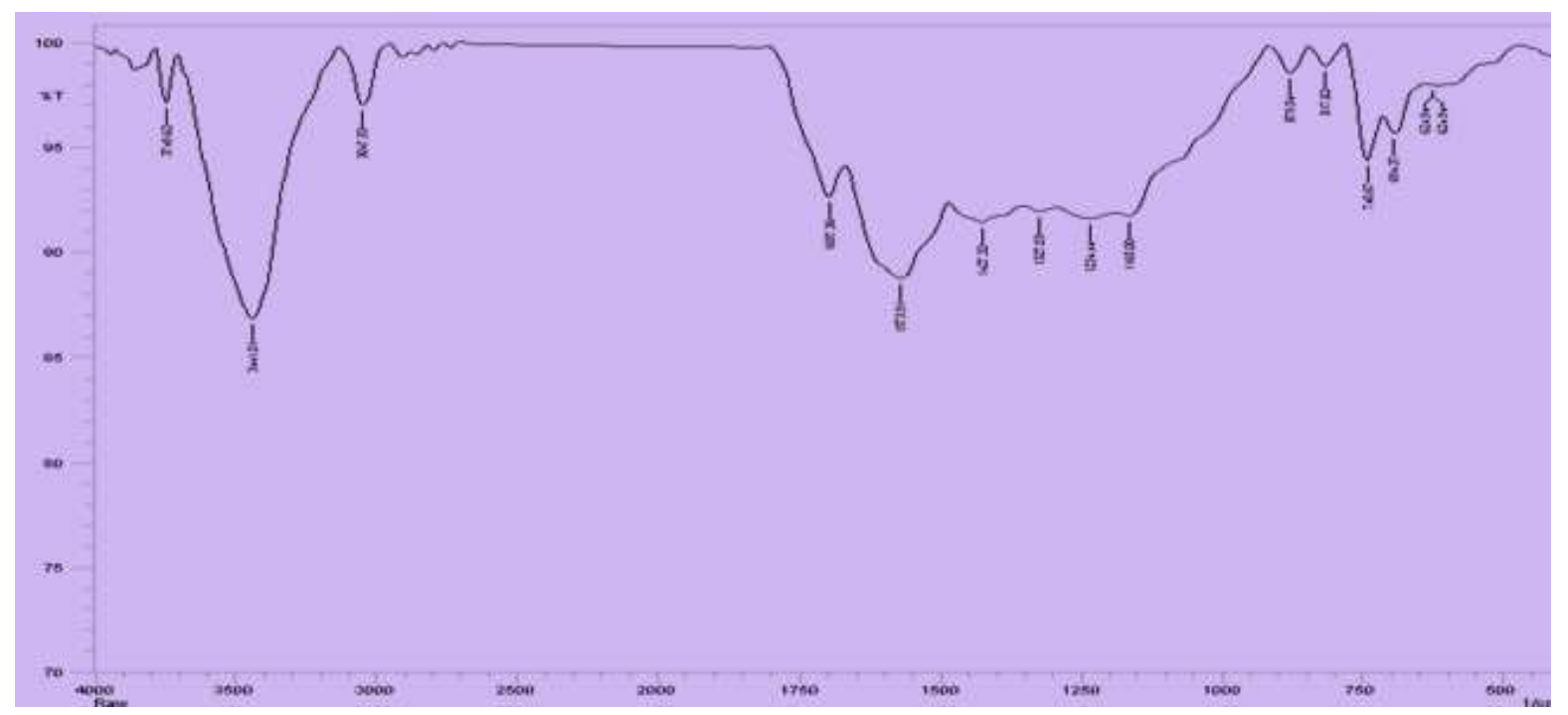

Fig.1. FTIR spectrum of activated carbon at $450^{\circ} \mathrm{C}$ 
The band (Fig.3) at $1118.71 \mathrm{~cm}^{-1}$ could be assigned to stretching vibrations of $\mathrm{C}-\mathrm{O}-\mathrm{C}$ in aromatic esters. However, the peak at $1165 \mathrm{~cm}^{-1}$ can be assigned to the stretching vibration of hydrogen-bonded $\mathrm{P}=\mathrm{O}$ groups from phosphates or polyphosphates, to the $\mathrm{O}-\mathrm{C}$ stretches vibration in the $\mathrm{P}-\mathrm{O}-\mathrm{C}$ (aromatic) linkage. Therefore, oxygen and phosphorus enriched carbon were observed [17]. The observation of those extra peaks suggests that the biochar surface was well modified in situ with the pyrolysis process, and the properties of the asobtained carbon surface was significantly enhanced by covering functional groups and mineral precipitants, and then greatly strengthen the adsorption performance [18].
As shown in Fig.4, many peaks were detected such as the broad peak at $3433.29 \mathrm{~cm}^{-1}$, low peak at $2916.37 \mathrm{~cm}^{-1}$, another peak at $1612.49 \mathrm{~cm}^{-1}$ with shoulder peak at $1705.07 \mathrm{~cm}^{-1}$ and a sharp peak at $1041 \mathrm{~cm}^{-1}$. These peaks correspond to the functional groups of $\mathrm{O}-\mathrm{H}$ stretching, $\mathrm{C}-\mathrm{H}, \mathrm{C}=\mathrm{O}$ and $\mathrm{C}-\mathrm{O}$ stretching, respectively. These findings revealed that the $\mathrm{OH}-\mathrm{AC}$ has $\mathrm{OH}, \mathrm{CO}$ and $\mathrm{COOH}$ as their functional groups. The addition of $\mathrm{NaOH}$ onto AC may increase the amount of the functional groups on $\mathrm{OH}-\mathrm{AC}$, and $\mathrm{NaOH}$ has $\mathrm{OH}$ groups. The presence of these functional groups will make the surface of the adsorbents to be more hydrophilic and thus could enhance the adsorption of positive metal ions [19 and 20].

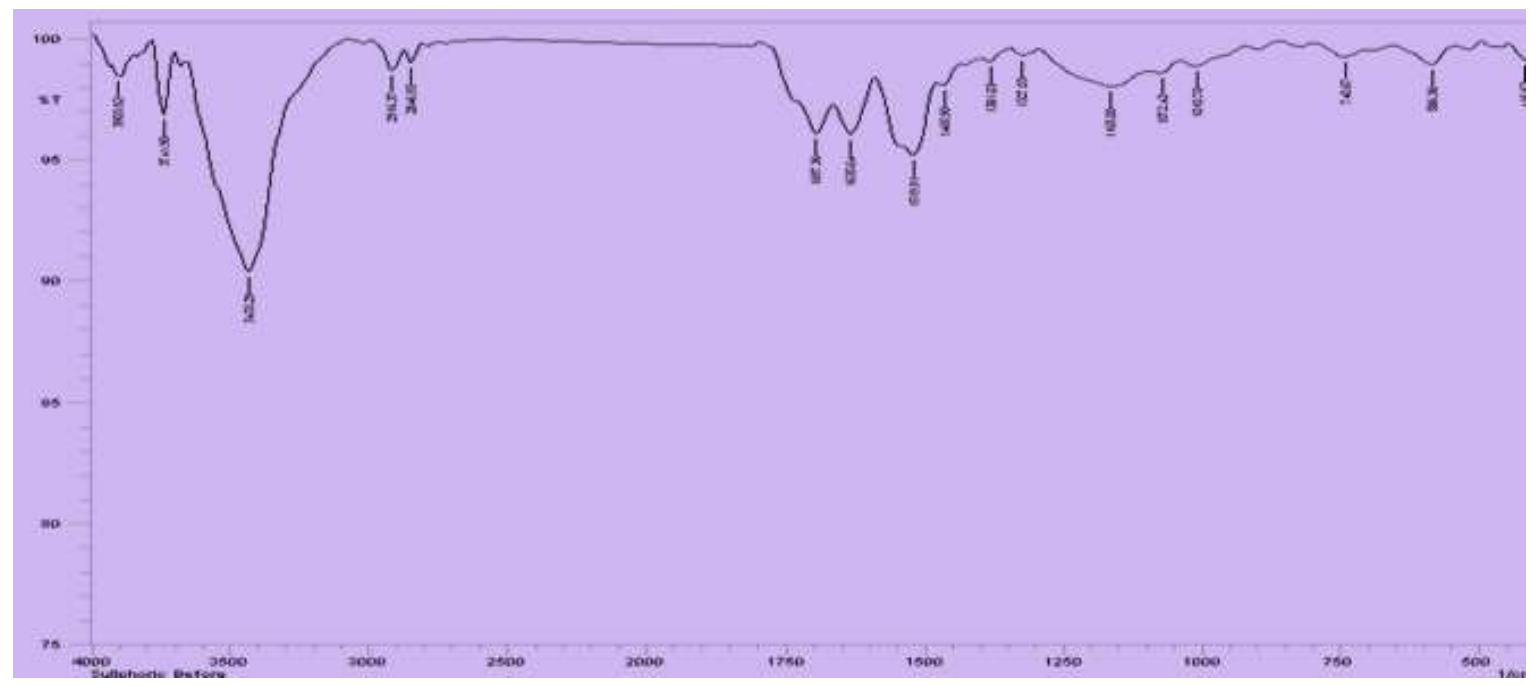

Fig. 2. FTIR spectrum of sulphonic activated carbon (S-AC)

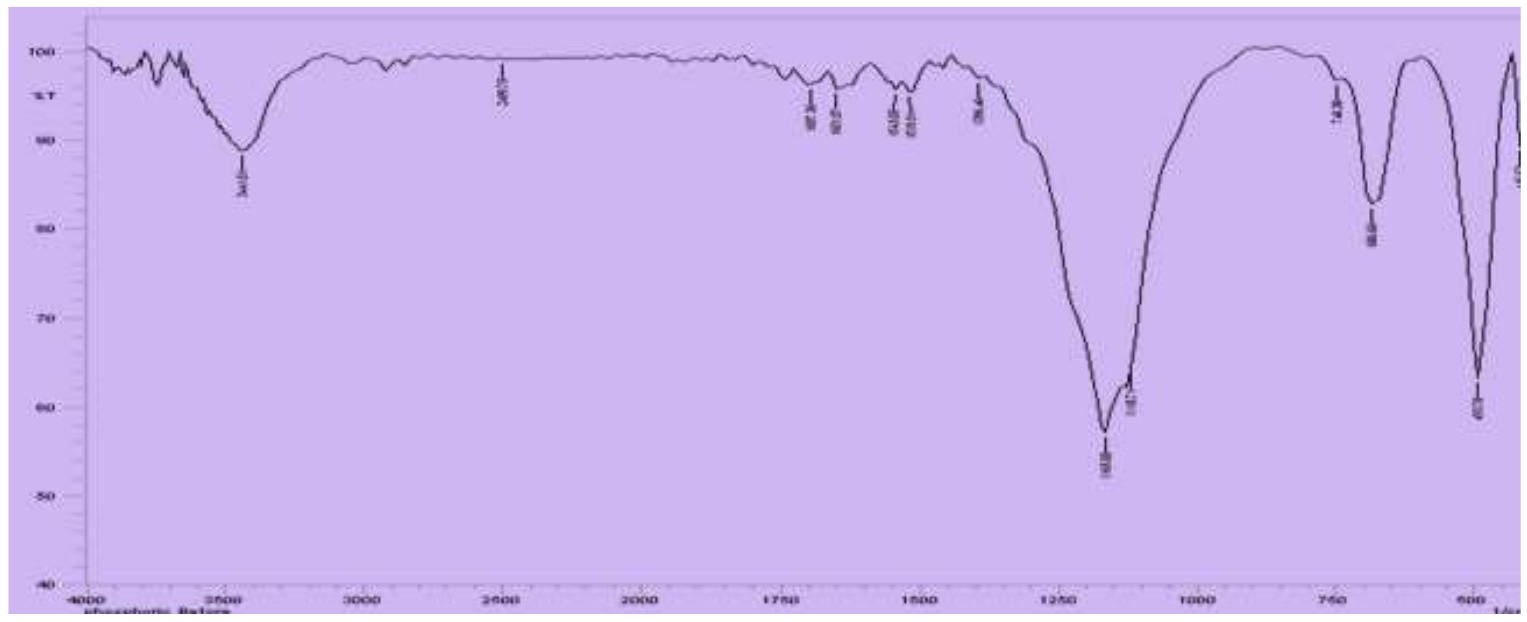

Fig. 3.FTIR spectrum of phosphoric activated Carbone (P-AC) 


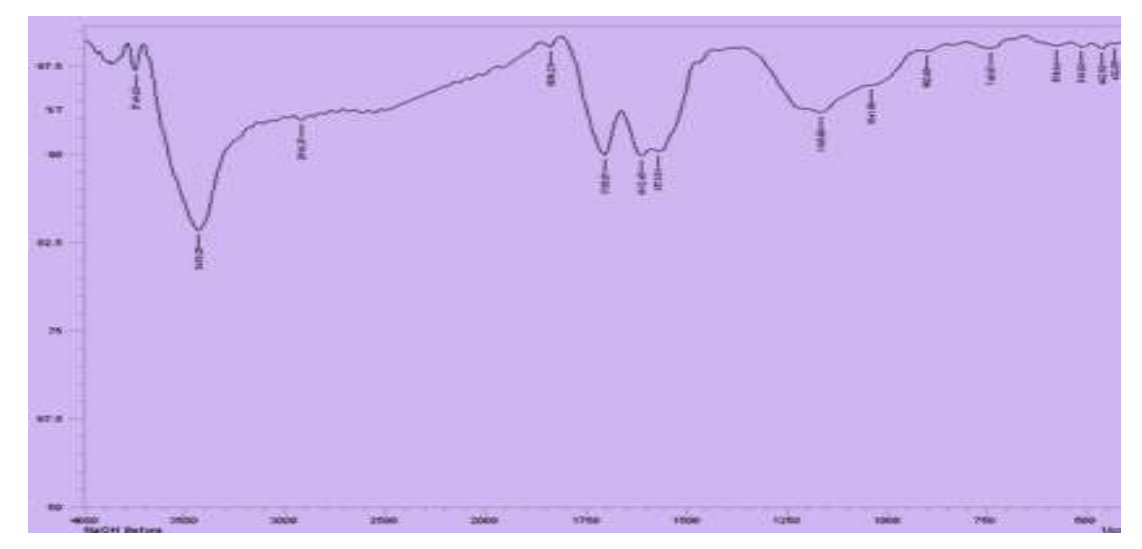

Fig. 4.FTIR spectrum of Hydroxyl activated Carbone (OH-AC)

\author{
Influencing factors on the removal \\ efficiency of $\mathrm{Mn}(\mathrm{II})$
}

\section{Effects of pH}

The effect of $\mathrm{pH}$ on the removal efficiency of $\mathrm{Mn}$ (II) was investigated in the range of 2 to 5.8. As shown in Fig.5, the removal efficiency and uptake of $\mathrm{Mn}(\mathrm{II})$ change by changing the $\mathrm{pH}$ value in the range of 2 to 5.8. However, in case of using $\mathrm{S}-\mathrm{AC}$, by increasing the $\mathrm{pH}$ value from 2 to $4, \mathrm{Mn}$ (II) removal efficiency increases from 75 to $78 \%$ (18.5 to $19.5 \mathrm{mg} / \mathrm{g}$ ) and then decreases to reach $76 \%$ at $\mathrm{pH}$ 5.8. Where by using $\mathrm{OH}-\mathrm{AC}$, it was found that the $\mathrm{Mn}$ (II) removal efficiency decreases gradually from $72 \%(18 \mathrm{mg} / \mathrm{g})$ until reach to $67 \%(16.75 \mathrm{mg} / \mathrm{g})$ with increasing the $\mathrm{pH}$ from 2 to 5.8.Finally, at using P-AC, it was shown that, the $\mathrm{Mn}$ (II) removal efficiency increases as the $\mathrm{pH}$ increase until reach to $32 \%(8 \mathrm{mg} / \mathrm{g})$ at $\mathrm{pH} 3$ and then decreases to $26 \%(7 \mathrm{mg} / \mathrm{g})$ at $\mathrm{pH}$ 5.8. The low uptake of $\mathrm{Mn}$ (II) is observed at lower $\mathrm{pH}$ value and this can be attributed to the large quantities of protons that competes with $\mathrm{Mn}$ (II) ions at the adsorption sites. In other words, by increasing $\mathrm{pH}$ value, more positively charged $\mathrm{Mn}(\mathrm{II})$ ions are adsorbed by free binding sites due to a larger portion of dissociation of protons from functional groups, resulting in the promotion of adsorption capacity [21]. The maximum $\mathrm{Mn}(\mathrm{II})$ removal efficiency of $78 \%(\mathrm{pH}=4), 32 \%(\mathrm{pH}=3)$ and $72 \%(\mathrm{pH}=2)$ by the S-AC, P-AC and OH-AC, respectively. Then the worked resins are arranged in the order $\mathrm{S}-\mathrm{AC}>\mathrm{P}-\mathrm{AC}>\mathrm{OH}-\mathrm{AC}$ with varying $\mathrm{pH}$ value.

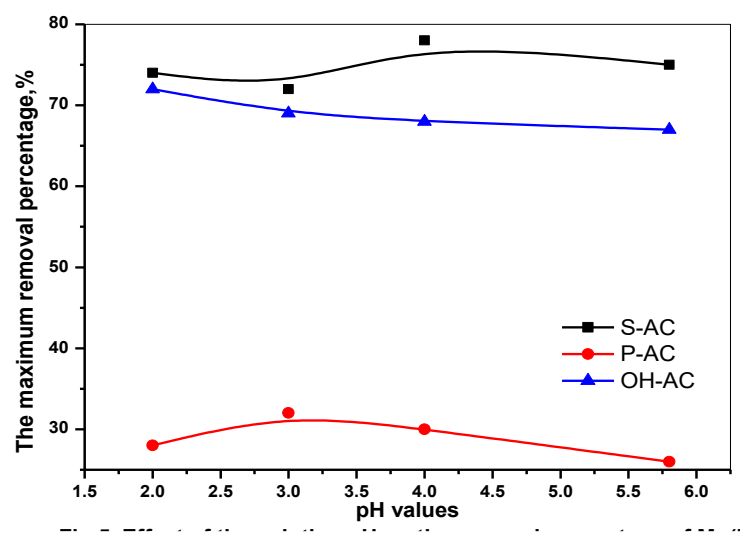

Fog. 5 Effect of the solution $\mathbf{p H}$ on the removal percentage of Mn (II)

\section{Effect of the adsorbent dosage}

Adsorbent dosage is a key parameter in the determination of removal efficiency and adsorption capacity. As the adsorbent dosage is increased, the available adsorption sites are also increasing; consequently, a better adsorption takes place. The effect of S-AC,P-AC and OHAC dosage on the removal efficiency and uptake of $\mathrm{Mn}$ (II) from the solution can be studied in varying dosage $0.1,0.2,0.3$ and $0.4 \mathrm{~g}$ at $\mathrm{pH}$ values 4,3 and 2 for $\mathrm{S}-\mathrm{AC}, \mathrm{P}-\mathrm{AC}$ and $\mathrm{OH}-$ AC respectively, contact time $4 \mathrm{hrs}$ and at a constant concentration (50ppm) of the initial manganese solution (Fig.6).It was shown from Fig.6thatthere is an increase in the removal efficiency from 64 to $94 \%, 58$ to $88 \%$ and 18 to $60 \%$ for S-AC,OH-AC and P-AC respectively, with increasing the dosage from 0.1 to $0.4 \mathrm{~g}$. This can be attributed to the fact that by increasing the adsorbent dosage, the density of the available reactive groups on the adsorbent 
surface for metal binding increases. While an opposite trend was observed where, the adsorption capacity decreases with increasing the adsorbent dosage. As the S-AC adsorbent dosage increases from 0.1 to $0.4 \mathrm{~g}$, a decrease in the $\mathrm{Mn}$ (II) adsorption capacity from 8 to $2.94,2.25$ to 1.875 and 2.75 to $2.75 \mathrm{mg} / \mathrm{g}$ was observed, respectively. Thismay be due to the interference existed between the binding sites and adsorbent, or the insufficiency of $\mathrm{Mn}$ (II) ions in the solution with respect to available binding sites [21].

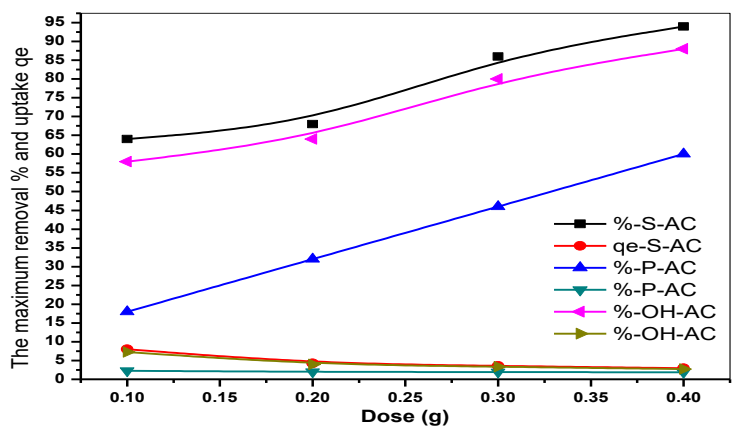

Fig. 6. Effect of the carbon doses on the removal $\%$ and uptake of $\mathrm{Mn}(\mathrm{II})$

The effect of the initial solution concentration on the $\mathrm{Mn}$ (II) removal efficiency by the concerned adsorbent was studied at initial $\mathrm{Mn}$ (II) concentration varies between $50,75,100,125$ and $150 \mathrm{mg} / \mathrm{L}$ (Fig.7). The removal efficiency of $\mathrm{Mn}(\mathrm{II})$ onto S-AC450 $0^{\circ} \mathrm{C}$, $\mathrm{P}-\mathrm{AC} 450^{\circ} \mathrm{C}$ and $\mathrm{OH}-\mathrm{AC} 450^{\circ} \mathrm{C}$ decreases from 64 to $58 \%, 18$ to $12 \%$ and 58 to $54.6 \%$, respectively, by increasing its initial concentration from 50 to $150 \mathrm{mg} / \mathrm{L}$. The removal efficiency is low at the highest concentration of $\mathrm{Mn}$ (II) due to the lower available adsorption sites in comparison with the number of $\mathrm{Mn}$ (II) ions. In brief, the performance of the S-AC, P-AC and OH-AC was evaluated by their removal percentages which were obtained as 64,18 and $58 \%$ for S$\mathrm{AC}, \mathrm{P}-\mathrm{AC}$ and $\mathrm{OH}-\mathrm{AC}$ respectively, where the adsorption capacities of S-AC,P-AC and $\mathrm{OH}-$ AC change from 8 to $21.75 \mathrm{mg} / \mathrm{g}, 2.25$ to $4.5 \mathrm{mg} / \mathrm{g}$ and 7.25 to $20.5 \mathrm{mg} / \mathrm{g}$, respectively, by increasing $\mathrm{Mn}(\mathrm{II})$ initial concentration from 50 to $150 \mathrm{mg} / \mathrm{L}$. This is confirmed with Saharan et al.,2019[22]who stated that the higher initial concentration of $\mathrm{Mn}(\mathrm{II})$ provides a driving force to overcome the mass transfer resistance between the aqueous and solid phases.

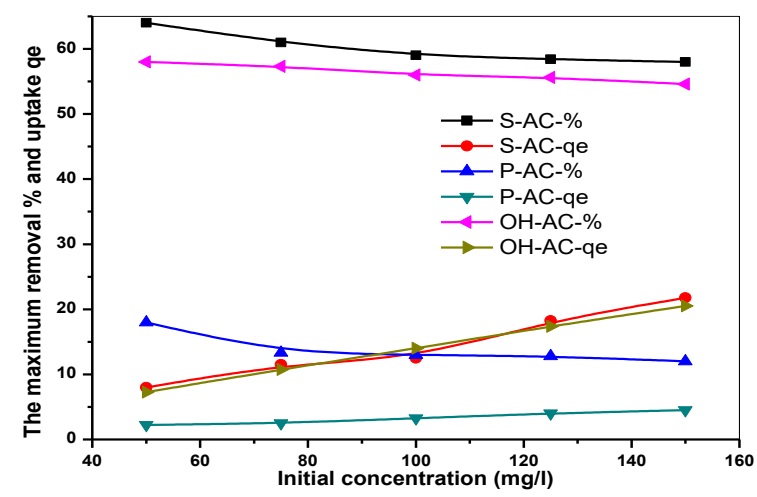

Fig. 7. Effect of the initial concentration on the removal \% and uptake of $\mathrm{Mn}(\mathrm{II})$

\section{Effect of contact time and activation temperature on the $\mathrm{Mn}$ (II) removal}

The effect of contact time on the removal of $\mathrm{Mn}(\mathrm{II})$ from the groundwater was achieved at different time varies from 1 to $300 \mathrm{~min}$ by two groups of activated carbons that have burned at two temperatures. The first group includes S-AC $450^{\circ} \mathrm{C}, \mathrm{P}-\mathrm{AC} 450^{\circ} \mathrm{C}$ and $\mathrm{OH}-\mathrm{AC}$ $450^{\circ} \mathrm{C}$, and the second group includes $\mathrm{S}-\mathrm{AC}$ $900^{\circ} \mathrm{C}, \quad \mathrm{P}-\mathrm{AC} \quad 900^{\circ} \mathrm{C}$ and $\mathrm{OH}-\mathrm{AC} \quad 900^{\circ} \mathrm{C}$ (Fig.8). It was observed that the removal of $\mathrm{Mn}$ (II) by S-AC $450^{\circ} \mathrm{C}, \mathrm{P}-\mathrm{AC} 450^{\circ} \mathrm{C}$ and $\mathrm{OH}-$ $\mathrm{AC} 450^{\circ} \mathrm{C}$ increases by increasing contact time till reaches to $0.975,0.95$ and $0.725 \mathrm{mg} / \mathrm{g}$, respectively, at contact time $300 \mathrm{~min}$, while the removal of $\mathrm{Mn}$ (II) by S-AC $900^{\circ} \mathrm{C}, \mathrm{P}-\mathrm{AC} 900^{\circ} \mathrm{C}$ and $\mathrm{OH}-\mathrm{AC} \quad 900^{\circ} \mathrm{Cincreases}$ by increasing contact time till reaches to $0.625,0.425$ and $0.725 \mathrm{mg} / \mathrm{g}$, respectively, at contact time $240 \mathrm{~min}$. The increase of the adsorption process at the beginning of the contact time may be due to a large number of active sites being available on the adsorbent surface for $\mathrm{Mn}(\mathrm{II})$ adsorption [23].

Fig.8. shows the effect of activation temperature $\left(450\right.$ and $\left.900^{\circ} \mathrm{C}\right)$ on the adsorption capacity of $\mathrm{Mn}$ (II) removal from the groundwater at fixed modification $\left(\mathrm{H}_{2} \mathrm{SO}_{4}\right.$, $\mathrm{H}_{3} \mathrm{PO}_{4}$ and $\mathrm{NaOH}$ ) and activation time of 300 and 240min, respectively. It was observed that, large manganese uptake capacity was obtained at the activation temperature up to $450^{\circ} \mathrm{C}$ and this may be due to the formation of a large amount of micro and mesopores. In other words, this may be also due to increase in surface area and total pore volume. In brief, further increase in activation temperature up to $900^{\circ} \mathrm{C}$ lead to a decrease in manganese uptake 
capacity and this probably due to burning of micro and mesopores and matrix of carbon collapsed causing blockage of pores [24].

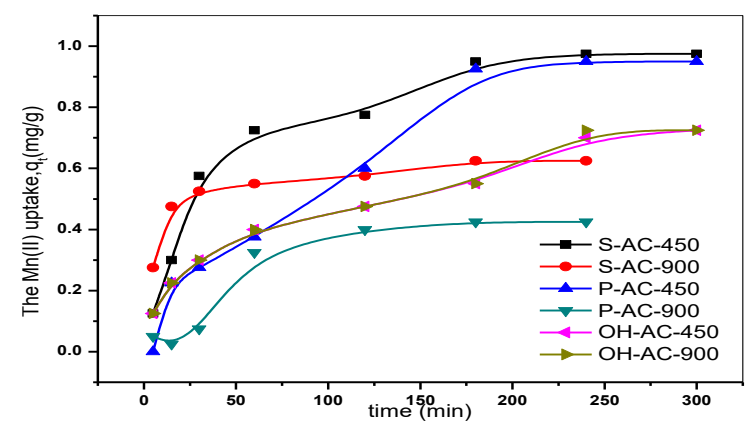

Fig. 8. Effect of activation temperature and Contac time on the Mn(II) uptake (5m g/l, 296K., $25 \mathrm{ml}$ and $0.1 \mathrm{~g}$ carbon)

\section{Adsorption kinetics studies}

Adsorption kinetics studies help in assessing the adsorption mechanisms in terms of order and rate constants, and provides useful information on possible rate control steps. Four kinetic models, pseudo-first-order [25], pseudosecond-order [26], Elovich[27] and intraparticle diffusion [28] were used to study the kinetics of the adsorption process of manganese by two groups of activated carbons, first group includes $\mathrm{S}-\mathrm{AC} 450^{\circ} \mathrm{C}, \mathrm{P}-\mathrm{AC} 450^{\circ} \mathrm{C}$ and $\mathrm{OH}-\mathrm{AC}$ $450^{\circ} \mathrm{C}$, and second group includesS-AC $900^{\circ} \mathrm{C}$, $\mathrm{P}-\mathrm{AC} 900^{\circ} \mathrm{C}$ and $\mathrm{OH}-\mathrm{AC} 900^{\circ} \mathrm{C}$. The kinetic graphs obtained are depicted in figures Nos. 9,10, 11 and 12,respectively, and the linearized equation and plot parameters are summarized in table (1).

\section{The pseudo-first order model}

The pseudo-first order model equation is generally expressed as follows;

$\frac{\mathrm{dq}}{\mathrm{dt}}=k_{1}\left(\mathrm{q}_{\mathrm{e}}-\mathrm{q}_{\mathrm{t}}\right)$

Where $\mathrm{q}_{\mathrm{e}}$ and $\mathrm{q}_{\mathrm{t}}$ are the amount of metal sorbed per unit weight of sorbent at equilibrium and at any time $\mathrm{t}(\mathrm{mg} / \mathrm{g})$, respectively, and $\mathrm{k}_{1}$ is the rate constant of pseudo-first order sorption $\left(\mathrm{min}^{-1}\right)$. After integration and applying boundary conditions, for $\mathrm{t}=0$ and $q=0$, the integrate form of Eq. (3) became

$$
\ln \left(\mathrm{q}_{\mathrm{e}}-\mathrm{q}_{\mathrm{t}}\right)=\ln \mathrm{q}_{\mathrm{e}_{\mathrm{i}} 1}-\frac{\boldsymbol{k}_{1} t}{2} \cdot 303
$$

The values of rate constant $\left(k_{1}\right)$ and equilibrium capacity (q_(e, $1, c a l)$ ) can be obtained from the slope and intercept of plotting $\log \left(q_{e}-q_{t}\right)$ against time for three temperatures.

\section{The pseudo-second order model}

If the rate of sorption is a second order mechanism, the pseudo-second order chemisorption kinetic rate equation is expressed as;

$\frac{\mathrm{dq}}{\mathrm{dt}}=\boldsymbol{k}_{2}\left(\mathrm{q}_{\mathrm{e}}-\mathrm{q}_{\mathrm{t}}\right)^{2}$

Where $k_{2}$ is the rate constant of pseudosecond order sorption $[\mathrm{g} /(\mathrm{mg} \min )], \mathrm{q}_{\mathrm{e}}$ is the amount of solute sorbet at equilibrium $(\mathrm{mg} / \mathrm{g}$ ) and $\mathrm{q}_{\mathrm{t}}$ is the amount of solute sorbet on the surface of the adsorbent at any time $\mathrm{t}(\mathrm{mg} / \mathrm{g})$.

Integrating this equation (4) for the boundary conditions for $t=0, q=0$ gives

$$
\begin{aligned}
\frac{\mathrm{t}}{\mathrm{q}} & =\frac{1}{\mathrm{k}_{2} \mathrm{q}_{\mathrm{e}, 2}^{2}}+\frac{1}{\mathrm{q}_{\mathrm{e} 2}} \mathrm{t} \\
h & =\mathrm{k}_{2} \mathrm{q}_{\mathrm{e}, 2}^{2}-{ }_{-}
\end{aligned}
$$

Where $\mathrm{h}[\mathrm{mg} /(\mathrm{g} \min )]$ means the initial adsorption rate, and the constants can be determined experimentally by plotting of $\mathrm{t} / \mathrm{q}$ against $t$.

\section{Elovich kinetic model}

The Elovich kinetic modelequation is generally expressed as follows;

$$
\mathrm{q}_{\mathrm{t}}=\frac{1}{\bar{\beta}} \ln (\alpha \beta)+\overline{\boldsymbol{\beta}}_{\operatorname{\beta int}}
$$

Where $\alpha$ is the initial adsorption rate in $\mathrm{mg} /(\mathrm{g} \cdot \mathrm{min})$ and $\beta(\mathrm{g} / \mathrm{mg})$ is the desorption constant related to the extent of the surface coverage and activation energy for chemisorption. Both the kinetic constants $\alpha$ and $\beta$ will be estimated from the slope and intercept of the plot of $q_{t}$ versus $\ln (t)$.

\section{Intra-particle diffusion equation}

The intra particle diffusion equation is the following;

$$
q_{t}=K_{\text {int }} t^{0.5}+C
$$

Where $K_{\text {int }}$ is the intraparticle diffusion rate coefficient $\left(\mathrm{mg} \mathrm{g}^{-1} \mathrm{~min}^{1 / 2}\right)$ and $C\left(\mathrm{mg} \mathrm{g}^{-1}\right)$ provides an idea about the thickness of the 
boundary layer.The $K_{\text {int }}$ and $C$ can be obtained from the slope and intercept of a straight line plot of $q_{t}$ versus $t^{0.5}$.

It was shown that the data obtained from the adsorption experiments of $\mathrm{Mn}$ (II) onto the first group of activated carbons at $450^{\circ} \mathrm{C}$ that namely; $\mathrm{S}-\mathrm{AC} 450^{\circ} \mathrm{C}, \mathrm{P}-\mathrm{AC} 450^{\circ} \mathrm{C}$ and $\mathrm{OH}-$ $\mathrm{AC} 450^{\circ} \mathrm{C}$ were summarized in table (1). As in the table(1), it is evident that the correlation coefficient $\left(R^{2}\right)$ values obtained by pseudofirst-order model are 0.89775 and 0.79645 for $\mathrm{Mn}$ (II) adsorption onto S-AC450 ${ }^{\circ} \mathrm{C}$ and $\mathrm{OH}-$ $\mathrm{AC} 450^{\circ} \mathrm{C}$, respectively, which are low in comparison with that obtained by pseudosecond-order model $(0.99015$ and 0.95541$)$ for $\mathrm{S}-\mathrm{AC} 450^{\circ} \mathrm{C}$ and $\mathrm{OH}-\mathrm{AC} 450^{\circ} \mathrm{C}$, respectively.

The lower values of the obtained $R^{2}$ from the pseudo-first-order model indicate the unsuitability of this model for predicting the adsorption of $\mathrm{Mn}$ (II) onto the $\mathrm{S}-\mathrm{AC} 450^{\circ} \mathrm{C}$ and $\mathrm{OH}-\mathrm{AC} 450^{\circ} \mathrm{C}$.Thus,pseudo-second-order model is appropriate for predicting the adsorption process of $\mathrm{Mn}$ (II) onto the $\mathrm{S}$ $\mathrm{AC} 450^{\circ} \mathrm{C}$ and $\mathrm{OH}-\mathrm{AC} 450^{\circ} \mathrm{C}$.

On the other hand, the obtained correlation coefficient $\left(\mathrm{R}^{2}\right)$ value by pseudo-first-order model of $\mathrm{Mn}(\mathrm{II})$ adsorption onto the $\mathrm{P}$ $\mathrm{AC} 450^{\circ} \mathrm{C}(0.96642)$ is higher than that obtained by the pseudo-second-order model (0.82767) showing a good fit for pseudo-first-order model for adsorption of Mnonto the $\mathrm{P}-\mathrm{AC} 450^{\circ} \mathrm{C}$.

The Elovich coefficients can be obtained from the linear plot of qt versus $\ln (\mathrm{t})$. If the adsorption of manganese ions by using $\mathrm{S}$ $\mathrm{AC} 450^{\circ} \mathrm{C}, \quad \mathrm{P}-\mathrm{AC} 450^{\circ} \mathrm{C}$ and $\mathrm{OH}-\mathrm{AC} 450^{\circ} \mathrm{C}$ carbons fits the Elovich model, a plot of $\mathrm{qt}$ versus $\ln (t)$ should yield a linear relationship with a slope of $(1 / \beta)$ and an intercept of $1 / \beta \ln (\alpha \beta)$ [29]. As in table1, the correlation coefficients obtained by Elovich model showed good linearity with both $\mathrm{S}-\mathrm{AC} 450^{\circ} \mathrm{C}\left(\mathrm{R}^{2}=\right.$ $0.97284)$ and $\mathrm{OH}-\mathrm{AC} 450^{\circ} \mathrm{C} \quad\left(\mathrm{R}^{2}=0.93627\right)$, which means that this model is a good model for adsorption of $\mathrm{Mn}$ (II) on $\mathrm{S}-\mathrm{AC} 450^{\circ} \mathrm{C}$ and $\mathrm{OH}-\mathrm{AC} 450^{\circ} \mathrm{C}$.

On the other hand, it can also be observed that Elovich model gave an account of the occurrence of desorption process, while this model was poor fits for P-AC $450^{\circ} \mathrm{C}$ carbon $\left(\mathrm{R}^{2}=0.86538\right)$. It is clear that the correlation coefficients obtained were almost linear which indicated that Elovich model fitted well for adsorption by S-AC $450^{\circ} \mathrm{C}$ and $\mathrm{OH}-\mathrm{AC} 450^{\circ} \mathrm{C}$ and not fitted for adsorption byP-AC $450^{\circ} \mathrm{C}$. The model gave a good correlation for adsorption on highly heterogeneous surface carbon. Besides, it is also shown that along with surface adsorption, chemisorption was also a dominant phenomenon taking place [30].

The obtained correlation coefficients $\left(\mathrm{R}^{2}\right)$ of the intra-particle diffusion are 0.86338 , 0.93966 and 0.98133 , suggesting that two or more steps are involved in $\mathrm{Mn}(\mathrm{II})$ adsorption onto the S-AC450 ${ }^{\circ} \mathrm{C}, \mathrm{P}-\mathrm{AC} 450^{\circ} \mathrm{C}$ and $\mathrm{OH}-$ $\mathrm{AC} 450^{\circ} \mathrm{C}$, respectively. Higher values of the obtained $R^{2}$ from intra-particle diffusion model indicate that this model fitted well for adsorption of $\mathrm{Mn}$ (II) by P-AC $450^{\circ} \mathrm{Cand} \mathrm{OH}-$ $\mathrm{AC} 450^{\circ} \mathrm{C}$, respectively, while the lower value indicates the unsuitability of this model for predicting the adsorption of $\mathrm{Mn}$ (II) onto the SAC $450^{\circ} \mathrm{C}$ adsorbent.

Noteworthy to mention that, the adsorption processes of $\mathrm{Mn}$ (II) onto the second group of carbons were evaluated with different kinetic models. A plot of ln(qe-qt) versus $t$ (Fig.9) gave a linear curve, and the obtained results showed that the first-order rate constant $\left(\mathrm{k}_{1}\right)$ was found to be $0.01383,0.02564$ and 0.00658 for adsorption of manganese ions onto S-AC $900^{\circ} \mathrm{C}$, $\mathrm{P}-\mathrm{AC} 900^{\circ} \mathrm{C}$ and $\mathrm{OH}-\mathrm{AC} 900^{\circ} \mathrm{C}$, respectively, with a correlation coefficient values $\left(\mathrm{R}^{2}\right)$ of $0.67014,0.95482$ and 0.95709 for $\mathrm{S}-\mathrm{AC} 900^{\circ} \mathrm{C}$, $\mathrm{P}-\mathrm{AC} 900^{\circ} \mathrm{C}$ and $\mathrm{OH}-\mathrm{AC} 900^{\circ} \mathrm{C}$, respectively. The lower correlation coefficient value suggests that the pseudo-first-order model is not appropriate for $\mathrm{Mn}$ (II) adsorption onto SAC $900^{\circ} \mathrm{C}$, while the high correlation coefficient values suggest that the pseudo-firstorder model is best appropriate for $\mathrm{Mn}$ (II) adsorption onto both $\mathrm{P}-\mathrm{AC} 900^{\circ} \mathrm{C}$ and $\mathrm{OH}-\mathrm{AC}$ $900^{\circ} \mathrm{C}$.

The pseudo second-order model describes the adsorption equilibrium capacity as well as the chemisorptive behavior of the adsorption process. A plot of $t / q_{t}$ versus $t$ (Fig.10) gave a linear curve and high $\mathrm{R}^{2}$ value of 0.93727 and 0.92893 for $\mathrm{S}-\mathrm{AC} 900^{\circ} \mathrm{C}$ and $\mathrm{OH}-\mathrm{AC} 900^{\circ} \mathrm{C}$, respectively. These results implied that the pseudo-second-order model was best described for $\mathrm{Mn}(\mathrm{II})$ adsorption onto $\mathrm{S}-\mathrm{AC} 900^{\circ} \mathrm{C}$ and 
$\mathrm{OH}-\mathrm{AC} 900^{\circ} \mathrm{C}$, while it is not fitting for the adsorption of $\mathrm{Mn}(\mathrm{II})$ onto $\mathrm{P}-\mathrm{AC} 900^{\circ} \mathrm{C}\left(\mathrm{R}^{2}=\right.$ 0.00424).Also, this suggests that the ratelimiting step of the adsorption process is chemical adsorption.

The Elovich model helps in understanding the kinetics of chemisorptions of the adsorb ate on the solid surface of the adsorbent. The values for $a$ and $\beta$ are obtained from a plot of $q_{t}$ versus $1 \mathrm{nt}$ (Fig.11), and their values are presented in table (1).As in table 1, the obtained correlation coefficients by Elovich model was $0.91396,0.86312$ and 0.78213 for $\mathrm{OH}-\mathrm{AC}$ $900^{\circ} \mathrm{C}, \quad \mathrm{S}-\mathrm{AC} 900^{\circ} \mathrm{C}$ and $\mathrm{P}-\mathrm{AC} 900^{\circ} \mathrm{C}$, respectively, which means that the Elovich model was fitted for adsorption of $\mathrm{Mn}$ (II) onto $\mathrm{OH}-\mathrm{AC} 900^{\circ} \mathrm{C}$, while it was poor fitted for adsorption of $\mathrm{Mn}$ (II) ontoS-AC900 ${ }^{\circ} \mathrm{C}$ and $\mathrm{P}$ $\mathrm{AC} 900^{\circ} \mathrm{C}$.

Weber and Morris's intra-particle diffusion model helps to identify the diffusion mechanism and the rate-limiting step. The boundary layer thickness $(C)$ and intra-particle diffusion rate constant $\left(\mathrm{k}_{\mathrm{int}}\right)$ can be deduced from the intercept and slope of the plot of $\mathrm{q}_{\mathrm{t}}$ versus the square root of time $\left(\mathrm{t}^{1 / 2}\right)$, respectively. It was observed from the plot that, the adsorption process takes place in two phases. The first phase depicts the rapid adsorption of manganese ions over a certain period of time, whereas the adsorption rate became slower in the second phase. This could be due to the chemisorptive interactions during the first stages of the adsorption process followed by intra-particle diffusion in the second stage. From Fig.12, the lines failed to pass through the origin, which suggests that intra-particle diffusion cannot be considered the rate-limiting step. As in table 1, the obtained correlation coefficients by intra-particle diffusion model was $0.96744,0.85729$ and 0.65638 for $\mathrm{OH}-\mathrm{AC} 900^{\circ} \mathrm{C}, \mathrm{P}-\mathrm{AC} 900^{\circ} \mathrm{C}$ and SAC $900^{\circ} \mathrm{C}$, respectively, which means that the intra-particle diffusion model was fitted for adsorption of $\mathrm{Mn}$ (II) onto $\mathrm{OH}-\mathrm{AC} 900^{\circ} \mathrm{C}$, while it was poor fitted for adsorption of $\mathrm{Mn}$ (II) onto P-AC $900^{\circ} \mathrm{C}$ and S-AC $900^{\circ} \mathrm{C}$.

The previous results were shown that the activation temperature $\left(450^{\circ} \mathrm{C}\right)$ is the best temperature for activation of adsorbent carbons. The pseudo-first-order model is appropriate for predicting the adsorption process of $\mathrm{Mn}$ (II) onto the P-AC $450^{\circ} \mathrm{C}, \mathrm{P}-\mathrm{AC} 900^{\circ} \mathrm{CandOH}-\mathrm{AC}$ $900^{\circ} \mathrm{C}$, while the pseudo-second-order model is appropriate for predicting the adsorption process of $\mathrm{Mn}$ (II) onto the both $\mathrm{S}-\mathrm{AC} 450^{\circ} \mathrm{C}$, $\mathrm{S}-\mathrm{AC} \quad 900^{\circ} \mathrm{C}, \mathrm{OH}-\mathrm{AC} \quad 450^{\circ} \mathrm{Cand} \mathrm{OH}-\mathrm{AC}$ $900^{\circ} \mathrm{C}$.Also, Elovich modelis appropriate for predicting the adsorption process of $\mathrm{Mn}$ (II) onto the S-AC $450^{\circ} \mathrm{C}$, OH-AC $450^{\circ} \mathrm{C}$ and $\mathrm{OH}-$ AC $900^{\circ} \mathrm{C}$. Finally, the intra-particle diffusion model is appropriate for predicting the adsorption process of $\mathrm{Mn}$ (II) onto the $\mathrm{OH}-\mathrm{AC}$ $450^{\circ} \mathrm{C}, \mathrm{P}-\mathrm{AC} 450^{\circ} \mathrm{C}$ and $\mathrm{OH}-\mathrm{AC} 900^{\circ} \mathrm{C}$.

Table 1.Kinetic parameters of $\mathrm{Mn}^{2+}$ adsorption in aqueous solutions using different carbons

\begin{tabular}{|c|c|c|c|c|c|c|}
\hline Kinetic model & $\begin{array}{c}\text { S-AC } \\
\left(450 \mathrm{C}^{\mathrm{o}}\right)\end{array}$ & $\begin{array}{c}\text { S-AC } \\
\left(900 \mathrm{C}^{0}\right)\end{array}$ & $\begin{array}{c}\text { P-AC } \\
\left(450 C^{0}\right)\end{array}$ & $\begin{array}{c}\text { P-AC } \\
\left(900 \mathrm{C}^{0}\right)\end{array}$ & $\begin{array}{l}\text { OH- AC } \\
\left(450 \mathrm{C}^{0}\right)\end{array}$ & $\begin{array}{l}\text { OH-AC } \\
\left(900 C^{0}\right)\end{array}$ \\
\hline $\begin{array}{c}\text { PFO } \\
\text { qe,1,cal } \\
\text { k1 } \\
\mathbf{R}^{2} \\
\end{array}$ & $\begin{array}{l}0.8612 \\
0.0177 \\
0.8977\end{array}$ & $\begin{array}{l}0.2160 \\
0.0138 \\
0.6701\end{array}$ & $\begin{array}{l}0.9006 \\
0.0088 \\
0.9664\end{array}$ & $\begin{array}{c}0.544 \\
0.0256 \\
0.9548\end{array}$ & $\begin{array}{c}0.688 \\
0.0109 \\
0.7964 \\
\end{array}$ & $\begin{array}{l}0.5478 \\
0.0065 \\
0.9570\end{array}$ \\
\hline $\begin{array}{c}\text { PSO } \\
\text { qe,2,cal } \\
\mathbf{k}_{\mathbf{2}} \\
\mathbf{h} \\
\mathbf{R}^{2}\end{array}$ & \begin{tabular}{|l|}
1.118 \\
0.0238 \\
0.0298 \\
0.9901 \\
\end{tabular} & $\begin{array}{l}0.7881 \\
0.0641 \\
0.0398 \\
0.9372 \\
\end{array}$ & $\begin{array}{c}1.429 \\
5.5 \times 10^{-3} \\
0.0112 \\
0.8276 \\
\end{array}$ & $\begin{array}{c}1.177 \\
0.0024 \\
0.0034 \\
0.0042 \\
\end{array}$ & $\begin{array}{l}0.8007 \\
0.0246 \\
0.0158 \\
0.9554\end{array}$ & $\begin{array}{l}0.7566 \\
0.0296 \\
0.0169 \\
0.9289\end{array}$ \\
\hline $\begin{array}{c}\text { Elovich } \\
\boldsymbol{\beta} \\
\boldsymbol{\alpha} \\
\mathbf{R}^{2} \\
\end{array}$ & $\begin{array}{c}4.436 \\
0.0757 \\
0.9728\end{array}$ & $\begin{array}{l}11.550 \\
0.7746 \\
0.8631\end{array}$ & $\begin{array}{c}3.555 \\
0.0284 \\
0.8653\end{array}$ & $\begin{array}{c}7.917 \\
0.0185 \\
0.7821\end{array}$ & $\begin{array}{c}6.888 \\
0.0479 \\
0.9362\end{array}$ & $\begin{array}{c}7.160 \\
0.0497 \\
0.9139\end{array}$ \\
\hline $\begin{array}{c}\text { Intraprticle } \\
\text { diffusion } \\
\mathbf{K}_{\text {int }} \\
\mathbf{C} \\
\mathbf{R}^{2}\end{array}$ & $\begin{array}{l}0.0540 \\
0.1581 \\
0.8633\end{array}$ & $\begin{array}{l}0.0244 \\
0.3261 \\
0.6563\end{array}$ & $\begin{array}{c}0.0625 \\
-0.0495 \\
0.9396\end{array}$ & $\begin{array}{c}0.0409 \\
-\mathbf{0 . 0 8 1 5} \\
0.8572\end{array}$ & $\begin{array}{l}0.0385 \\
0.0691 \\
0.9813\end{array}$ & $\begin{array}{l}0.0403 \\
0.0587 \\
0.9674\end{array}$ \\
\hline
\end{tabular}




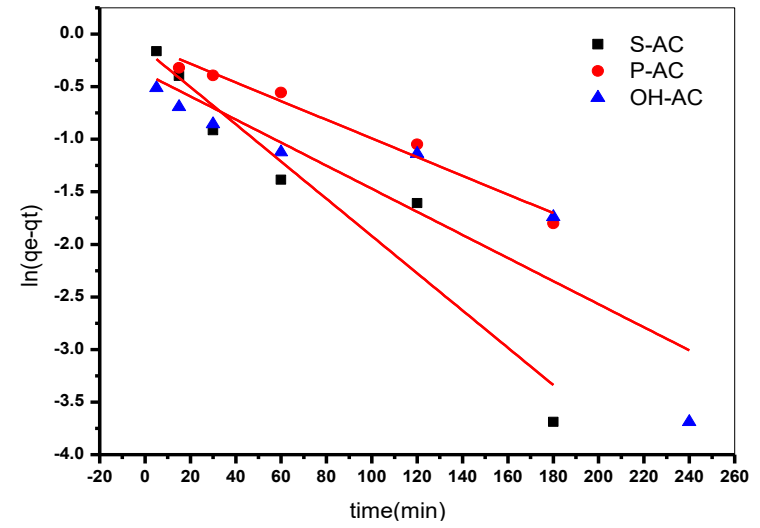

Fig. 9. Pseudo-first order plots of Mn(II)

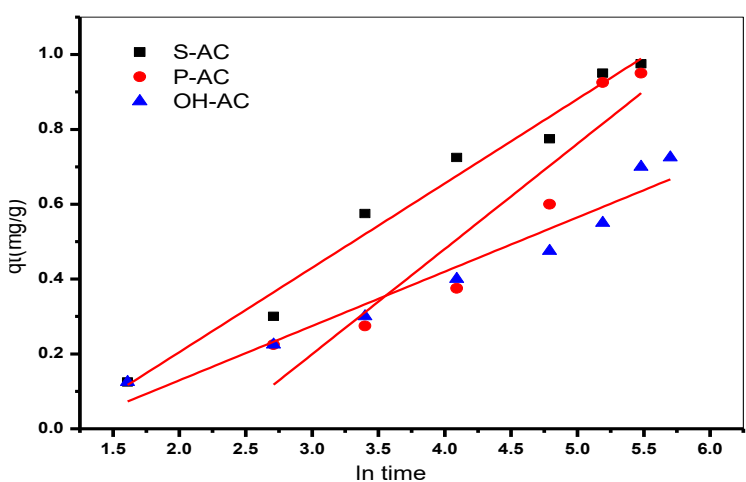

Fig. 10. Pseudo-second order plots of Mn(II)

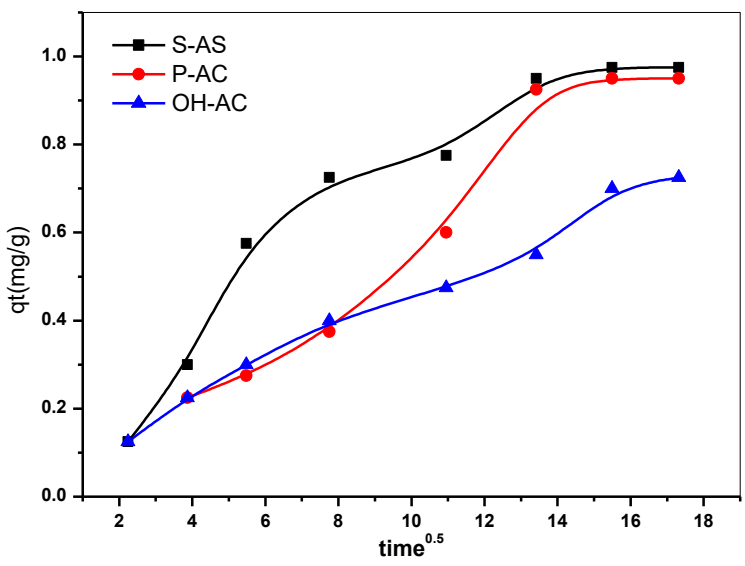

Fig. 11. Elovich plots of $\mathrm{Mn}(\mathrm{II}) 450^{\circ} \mathrm{C}$.

\section{Effect of temperature on the removal\% of $\operatorname{Mn}(\mathrm{II})$}

The effect of temperature is accepted as a major factor affects the adsorption. The effect of the solution temperature on the removal\% of $\mathrm{Mn}(\mathrm{II})$ by the activated carbons S-AC,P-AC and $\mathrm{OH}-\mathrm{AC}$ can be studied at temperature varies from 296 to 320k (Fig.13).As shown
inFig.13, the removal\% of $\mathrm{Mn}$ (II) by both S-AC and P-AC increases with increasing temperature till reaches to the maximum removal\% at the temperature $316 \mathrm{k}$ and then decreases with increasing temperature .The decrease in removal\% might be due to the reduction of the attraction forces between the adsorbate and adsorbent as a result of increase in temperature [31]. In addition, the high temperature can also promote the adsorption process by accelerating molecular thermal motion to facilitate the contact between target ions and the sorbent [32]. On the other hand, it was shown that the removal\% of the Mn(II) by $\mathrm{OH}-\mathrm{AC}$ decreases with increasing temperature .

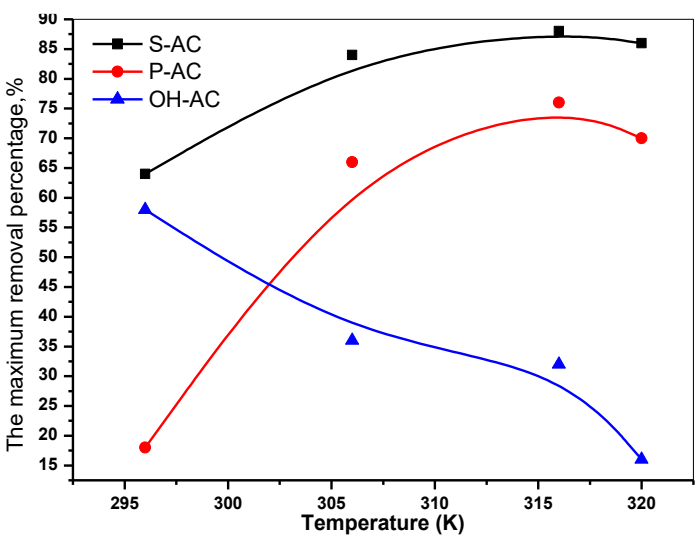

Fig. 13. Effect of the solution temperature on the removal percentage of $\mathrm{Mn}$ (II)

\section{Thermodynamic parameters}

Data given from the thermodynamic studies are important for predicting the adsorption mechanism of heavy metals from the polluted water and thiscan be achieved at various temperatures (296, 306, 316 and $320 \mathrm{~K})$. The thermodynamic parameters in particular are; Gibbs free energy $\left(\Delta \mathrm{G}^{\mathrm{o}}\right)$, enthalpy change $\left(\Delta \mathrm{H}^{\circ}\right)$ and standard entropy change $\left(\Delta \mathrm{S}^{\circ}\right)$ are computed by Eqs. 9 and 10 .

$$
\begin{aligned}
& \Delta \mathrm{G}^{\mathrm{o}}=-\mathrm{RT} \ln \mathrm{K}_{\mathrm{d}} \\
& \ln \mathrm{K}_{\mathrm{d}}=\mathrm{R}-\mathrm{RT}
\end{aligned}
$$

The thermodynamic results of manganese adsorption by S-AC, P-AC and OH-AC were shown in both Fig. 14 and table 2.The obtained negative $\Delta G^{\circ}$ values indicate favorable, spontaneous manganese adsorption by S-AC at the temperatures 306,316 and $320 \mathrm{~K}$, whereas, 
the manganese adsorption by both $\mathrm{P}-\mathrm{AC}$ and OH-AC at all the four temperatures 296, 306, 316 and $320 \mathrm{~K}$ was non spontaneous. The obtained positive $\Delta S^{\circ}$ values indicate an increase in the randomness of the solid/liquid interface, with structural changes in the adsorbate/adsorbent system [33]. In other words, the positive $\Delta \mathrm{H}^{\circ}$ values confirm the endothermic nature of the adsorption processes [34] using both S-AC and P-AC.

The Negative value of $\Delta \mathrm{H}^{\mathrm{o}}$ affirmed the exothermic nature of the adsorption procedure by $\mathrm{OH}-\mathrm{AC}$. This is this agrees with Das et al., 2014, [35], who stated that, the enthalpy value in the interval ranging from 2 to $20 \mathrm{~kJ} \mathrm{~mol}^{-1}$ points to physisorption, while the value inside $20-400 \mathrm{~kJ} \mathrm{~mol}^{-1}$ characterizes chemisorption. Hence, the obtained enthalpy values show in table(2) confirm that the chemisorption characteristics governs the uptake process of $\mathrm{Mn}(\mathrm{II})$ by both S-ACand P-AC. On the other side, the negative entropy value shows that diminished disorder ensues at the solid/solution interface throughout the adsorption procedure [36] by OH-AC material.

Table 2. Thermodynamic parameters of Mn(II) adsorbtion by S-AC, P-AC and OH-AC

\begin{tabular}{|c|c|c|c|c|}
\hline Temp. & Temp.K & $\begin{array}{c}\Delta \mathrm{G}^{0} \\
\mathrm{KJ} / \mathrm{Mol}\end{array}$ & $\begin{array}{c}\Delta \mathrm{H}^{0} \\
\mathrm{KJ} / \mathrm{Mol}\end{array}$ & $\begin{array}{c}\Delta \mathrm{S}^{0} \\
\mathrm{~J} / \mathrm{mol} . \mathrm{K}\end{array}$ \\
\hline & 296 & 1.966 & & \\
& 306 & -0.692 & & \\
& 316 & -0.159 & & \\
& 320 & -1.141 & & \\
\hline & 296 & 7.144 & & \\
& 306 & 1.839 & & \\
\cline { 2 - 3 } & 316 & 0.615 & & \\
\cline { 2 - 3 } & 320 & 1.434 & & \\
\hline \multirow{6}{*}{} & 296 & 2.636 & & \\
\cline { 2 - 3 } & 306 & 4.991 & & \\
\cline { 2 - 3 } & 316 & 5.622 & & \\
\cline { 2 - 3 } & 320 & 8.101 & & \\
\hline
\end{tabular}

The obtained results suggest that S-AC has high adsorption capacities for $\mathrm{Mn}^{2+}$ compared with other adsorbents, such as $\mathrm{P}-\mathrm{AC}$ and $\mathrm{OH}-$ AC. Therefore, S-AC can be used in groundwater treatment unit to give satisfactory results such as obtaining high removal efficiency.

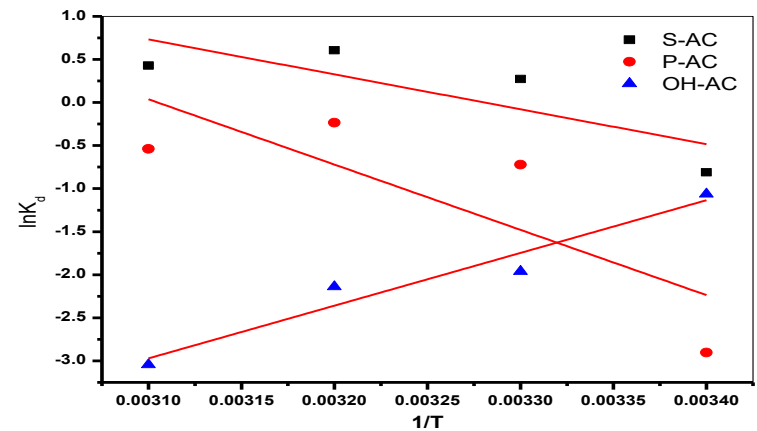

Fig. 14. Van't Hoff plots of $\mathrm{Mn}(\mathrm{II})$ in aqueous solutions

Treatment of the polluted groundwater in the Northwest coast area-Egypt

In this study, some of polluted groundwater samples were collected from the Northwest coast areaFig.15, and transported to the Desert Research Center laboratories to analyze based on the international standard methods according to Rainwater and Thatcher, 1960[37] and Fishman and Friedman, 1985[38] to determine both the major and trace constituents, respectively, in the collected water samples (Table3).As shown in table 3, it was noticed that some groundwater samples are unsuitable for drinking purposes as they have $\mathrm{Mn}^{+2}$ concentration more than the safe limit $(0.4 \mathrm{mg} / \mathrm{L} ; \mathrm{WHO}, 2011)$. So, it must be using an adsorbent (as S-AC) to decrease the concentration of manganese ion from this polluted groundwater to less than $0.4 \mathrm{mg} / \mathrm{L}$. To achieve this aim, the factors that affect on the adsorption process of $\mathrm{Mn}^{+2}$ from groundwater have been studied as the following;

Table 3 The concentrations of $\mathrm{Mn}$ (II) and $\mathrm{Zn}$ (II) in the collected groundwater samples in the study area

\begin{tabular}{|c|c|c|}
\hline $\begin{array}{c}\text { Sample } \\
\text { No }\end{array}$ & $\begin{array}{c}\text { Conc. of } \\
\text { Zinc (mg/L) }\end{array}$ & $\begin{array}{c}\text { Conc. of } \\
\text { Mn (mg/L) }\end{array}$ \\
\hline 1 & 0.122 & 0.126 \\
\hline 2 & 1.870 & 0.876 \\
\hline 3 & 0.919 & 0.028 \\
\hline 4 & 0.675 & 0.154 \\
\hline 5 & 0.150 & 0.024 \\
\hline 6 & 0.256 & 0.190 \\
\hline 7 & 0.016 & 0.008 \\
\hline 8 & 0.457 & 0.130 \\
\hline 9 & 0.363 & 0.015 \\
\hline 10 & 0.011 & 0.014 \\
\hline 11 & 1.820 & 0.013 \\
\hline 12 & 0.289 & 0.017 \\
\hline 13 & 0.264 & 0.015 \\
\hline 14 & 0.363 & 0.461 \\
\hline
\end{tabular}




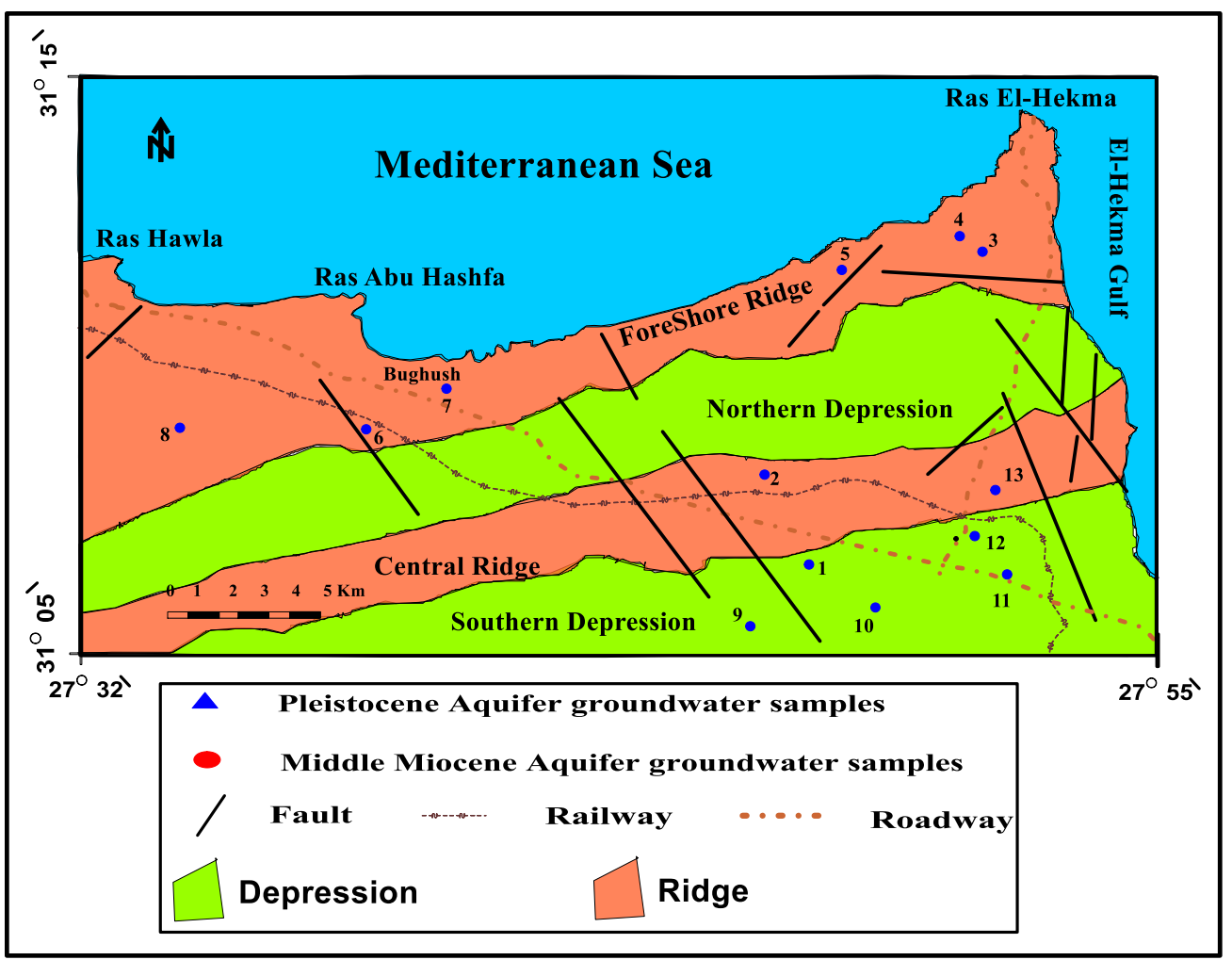

Fig.15 Groundwater samples sites location map

\section{Effect of the adsorbent dosageon the removal\% of $\mathrm{Mn}(\mathrm{II})$}

Adsorbent dosage has significant impact on the adsorption process as it determines the sorbent-sorbated equilibrium of the system [39]. The effect of the adsorbent dosage on the removal\% of $\mathrm{Mn}$ (II) from the polluted groundwater by S-AC was carried out at adsorbent dosages varies from 0.1 to $0.4 \mathrm{mg}$ for two groundwater samples Nos. (2 and 14) at pH 4.0and contact time 4h.Fig.16 shows that manganese ions removal efficiency from samples Nos.2 and 14 increased with increasing $\mathrm{S}$-AC dosages from 0.1 to $0.4 \mathrm{~g}$. The removal efficiency of $\mathrm{Mn}(\mathrm{II})$ by $\mathrm{S}-\mathrm{AC}$ increases gradually by increasing S-AC dosage till reach to the maximum values $(23 \%$ and $17.57 \%$ at samples Nos. 2 and 14, respectively. In brief, at constant initial $\mathrm{Mn}$ (II) concentration, with increasing the adsorbent dosage, the adsorption sites remain unsaturated. On the conrary, at low adsorbent dosage, all the active sites were exposed and occupied completely leading to saturation of the surface.

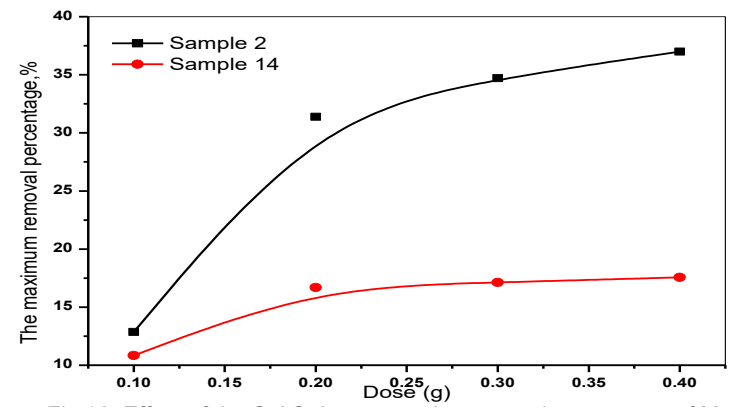

Fig. 16. Effect of the S-AC dosage on the removal percentage of $\mathrm{Mn}$ (II) from groundwater samples 2 and 14

Effect of the initial manganese concentration on the removal\% of $\mathrm{Mn}$ (II)

To evaluate the effect of the initial manganese concentration on the removal capacity of the concerned adsorbent, the experiments were carried out with varying initial manganese concentrations $(0.876$ and $0.431 \mathrm{mg} / \mathrm{L}$ )at $\quad 296 \mathrm{k}, \mathrm{pH} 4.0$ and $\quad 0.4 \mathrm{~g} \quad \mathrm{~S}-\mathrm{AC}$ adsorbent dosage till $4 \mathrm{~h}$ of contact time (Fig.17). It was observed that, a gradual increase in the adsorption capacity of S-AC from 0.0111 to $0.0297 \mathrm{mg} / \mathrm{g}$ and from 0.0025 to $0.0037 \mathrm{mg} / \mathrm{g}$ of samples Nos.2 and 14, 
respectively, and then decreases at high concentration to reach to 0.019 and $0.0033 \mathrm{mg} / \mathrm{g}$, respectively, with increase of initial manganese concentration. An increase in adsorption by S-AC with increase in manganese concentrations might be due to relative increase in mass transfer[40].

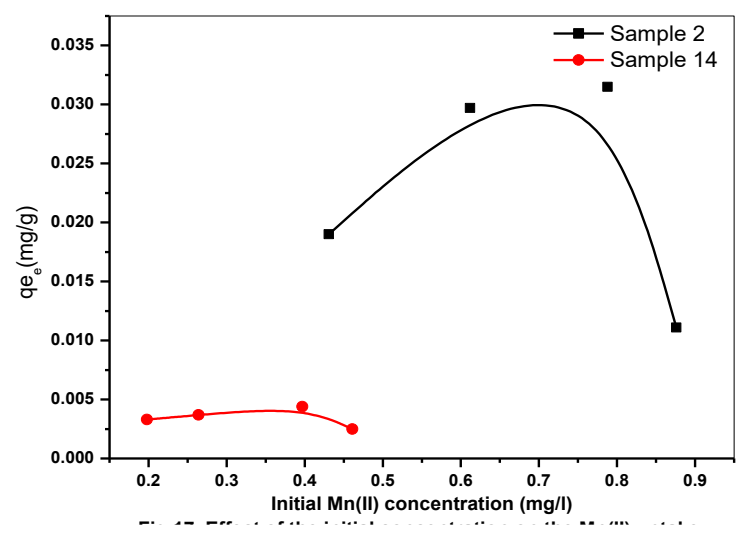

Fig. 17. Effect of the initial concentration on the Mn(II) uptake from groundwater samples 2 and 14.

\section{Effect of temperature on the removal\% of $\operatorname{Mn}($ II)}

Temperature is one of the most important factors, which might have a critical role on the proceeding of the adsorption process of $\mathrm{Mn}$ (II) from polluted groundwater. The effect of the temperature on the $\mathrm{Mn}^{2+}$ adsorption process from polluted groundwater onto the S-AC was investigated at 296, 306, 316 and 320K,S-AC adsorbent dosage $0.4 \mathrm{~g}$ and initial $\mathrm{Mn}(\mathrm{II})$ concentrations 0.876 and $0.431 \mathrm{mg} / \mathrm{Lfor}$ samples Nos.2\&14 and pH4.0atcontact time 4h (Fig.18).As shown inFig.18, the processes of $\mathrm{Mn}(\mathrm{II})$ removal\% from groundwater sample No.2 increases from 14.51 to $35.62 \%$ by increasing temperature from 296 to $316 \mathrm{~K}$ and then slightly decreases till reaches to $35.5 \%$ at temperature $320 \mathrm{k}$. While for groundwater sample No.14, the processes of $\mathrm{Mn}$ (II) removal\% increases from 10.84 to $16.05 \%$ with increasing temperature from 296 to $316 \mathrm{kand}$ the removal\% still constant(No change was observed) with increasing temperature till reach to $320 \mathrm{k}$. This increase of the removal adsorption with increasing temperature may be due to the development of new pores in the adsorbent and reduction in the viscosity of the medium. With increasing of swelling, the interaction between the adsorb ate ions and the binding sites on the adsorbent surface increases and this deal with increase the removal adsorption. In other words, the adsorption capacity increases at high temperature esdue to the superior diffusion rate of the metal ions and the lower solution viscosity of the adsorbent particles [41].

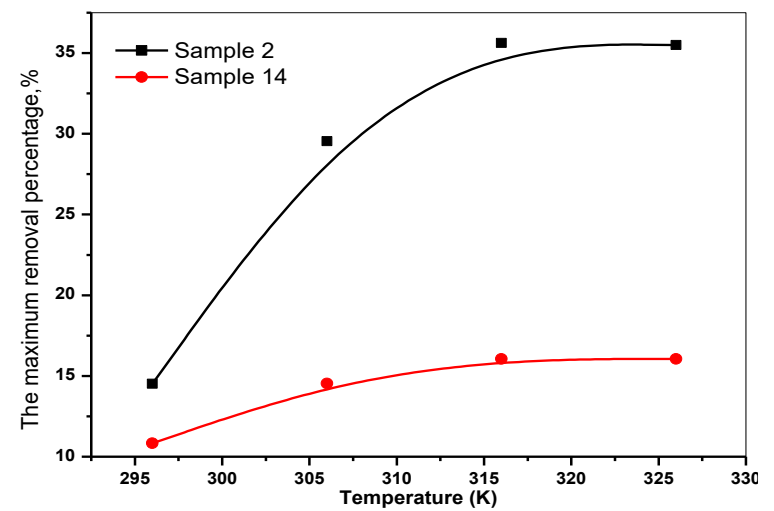

Fig. 18. Effect of the solution temperature on the removal percentage of $\mathrm{Mn}$ (II) from different grouundwater samples 2 and 14

Thermodynamic parameters for $\mathrm{Mn}^{2+}$ adsorption onto the S-AC carbon from different groundwater samples.

The estimated thermodynamic parameters values of the Van't Hoff equation (Eq.9) for $\mathrm{Mn}^{2+}$ adsorption on the S-AC from groundwater samples Nos.2 and 14, were listed in the table (4) and represented in Fig. 19. The positive values of $\Delta \mathrm{G}^{\circ}$ (Eq.10) at all four temperatures indicate that the adsorption reaction requires energy to carry out and also, the adsorption process has a non-spontaneous nature. The decrease of $\Delta \mathrm{G}^{\circ}$ change values as a function of temperature indicates that the adsorption may be favored at high temperature [42]. The positive $\Delta \mathrm{S}^{\circ}$ values indicate an increase in the randomness of the solid/liquid interface with structural changes in the adsorb ate/adsorbent system [43]. Also, the positive $\Delta \mathrm{H}^{\circ}$ values confirm that the endothermic nature of the adsorption processes were corroborate with the isotherm results. In brief, the adsorption capacities increase with the increase in temperature due to the increase in $\mathrm{Mn}^{2+}$ mobility and diffusion through the porous structures of the S-AC carbon, overcoming the activation energy. 
Table 4. Thermodynamic parameters for $\mathrm{Mn}$ (II) adsorption onto the $\mathrm{S}-\mathrm{AC}$ carbon from groundwater.

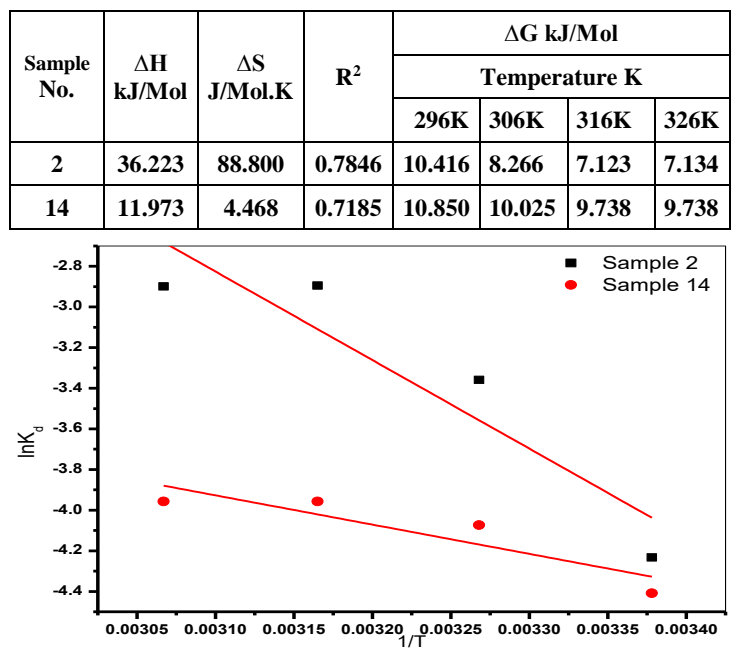

Fig. 19. Van't Hoff plots of manganese adsorption in different groundwater samples (S-2 and S-14)

\section{CONCLUSION}

In the present study, polystyrene divinyl benzene (Amberjet 1500 cation exchange resin) waste-derived carbon at $450^{\circ} \mathrm{C}$ and $900^{\circ} \mathrm{C}$ was prepared, characterized and applied as a costeffective adsorbent for manganese (Mn) removal from the polluted groundwater after the modification with $\mathrm{H}_{2} \mathrm{SO}_{4}(\mathrm{~S}-\mathrm{AC}), \mathrm{H}_{3} \mathrm{PO}_{4}$ $(\mathrm{P}-\mathrm{AC})$ and $\mathrm{NaOH}(\mathrm{OH}-\mathrm{AC})$. The effects of the functional parameters such as solution $\mathrm{pH}$, contact time, temperature and initial concentration on the Mn (II) removal efficiency by the activated carbons were evaluated. The activated carbons exhibited greater adsorption efficiency at $450^{\circ} \mathrm{C}$ than at $900^{\circ} \mathrm{C}$, this may be due to its porosity and surface functionality. The maximum adsorption was achieved at $\mathrm{pH}$ values 4,3 and 2, temperature 316, 316 and $296 \mathrm{~K}$, carbon dosage $0.4 \mathrm{~g}$, initial manganese concentration $150 \mathrm{mg} / \mathrm{l}$ and contact time of 4,4 and $5 \mathrm{~h}$ with modified activated carbons S-AC, $\mathrm{P}-\mathrm{AC}$ and $\mathrm{OH}-\mathrm{AC}$, respectively at $450^{\circ} \mathrm{C}$. While, with activated carbons at $900^{\circ} \mathrm{C}$, the optimum contact times was 3,3 and $4 \mathrm{~h}$ using S-AC, P-AC and $\mathrm{OH}-\mathrm{AC}$, respectively. Kinetically, it was shown that the temperature $450^{\circ} \mathrm{C}$ is the best temperature for activation of adsorbent carbons. It was observed that, the pseudo-first-order model is appropriate for the adsorption process of $\mathrm{Mn}(\mathrm{II})$ onto the P-AC $450^{\circ} \mathrm{C}, \mathrm{P}-\mathrm{AC} \quad 900^{\circ} \mathrm{CandOH}-\mathrm{AC} \quad 900^{\circ} \mathrm{C}$, while the pseudo-second-order model is appropriate for the adsorption process of $\mathrm{Mn}$ (II) onto the both S-AC $450^{\circ} \mathrm{C}, \quad \mathrm{S}-\mathrm{AC} \quad 900^{\circ} \mathrm{C}$, OH-AC $450^{\circ} \mathrm{Cand} \mathrm{OH}-\mathrm{AC} \quad 900^{\circ} \mathrm{C}$.Also, Elovich modelis appropriate for the adsorption process of $\mathrm{Mn}$ (II) onto the S-AC $450^{\circ} \mathrm{C}, \mathrm{OH}-\mathrm{AC} 450^{\circ} \mathrm{C}$ and $\mathrm{OH}-\mathrm{AC} \quad 900^{\circ} \mathrm{C}$. Finally, intraparticle diffusion models are appropriate for the adsorption process of $\mathrm{Mn}$ (II) onto the $\mathrm{OH}-\mathrm{AC}$ $450^{\circ} \mathrm{C}, \mathrm{P}-\mathrm{AC} \quad 450^{\circ} \mathrm{C}$ and $\mathrm{OH}-\mathrm{AC} \quad 900^{\circ} \mathrm{C}$. Thermodynamics calculations affirmed that $\mathrm{Mn}$ (II) adsorption processes onto S-AC and P$\mathrm{AC}$ was endothermic processes while the adsorption processes onto $\mathrm{OH}-\mathrm{AC}$ was exothermic process. The negative $\Delta \mathrm{G}^{\circ}$ values indicate that the adsorption was favorable and spontaneous adsorption on S-AC at the three temperatures 306,316 and $326 \mathrm{~K}$, whereas, the manganese adsorption by both $\mathrm{P}-\mathrm{AC}$ and $\mathrm{OH}-$ $\mathrm{AC}$ at all four temperatures 296, 306, 316 and $326 \mathrm{~K}$ was non spontaneous. In brief, the prepared S-AC, $\mathrm{P}-\mathrm{AC}$ and $\mathrm{OH}-\mathrm{AC}$ can be considered as an effective adsorbent for $\mathrm{Mn}$ (II) removal from aqueous solutions and polluted groundwater. While, the obtained results indicated that $\mathrm{S}$-AC has high adsorption capacities for $\mathrm{Mn}^{2+}$ compared with other adsorbents, such as P-AC and OH-AC. Therefore, S-AC $450^{\circ} \mathrm{Ccan}$ be used for groundwater treatment as it gives higher satisfactory removal efficiency.

\section{REFERENCES}

[1] Y. Guo, T. Huang, G. Wen, X. Cao The simultaneous removal of ammonium and manganese from groundwater by ironmanganese co-oxide filter film: the role of chemical catalytic oxidation for ammonium removal, Chem. Eng. J., 308 (2017), pp. 322329

[2] A.K. Rose, L. Fabbro, S. Kinnear Hydrogeochemistry in a relatively unmodified subtropical catchment: insights regarding the health and aesthetic risks of manganese, J. Hydrol.: Reg. Stud., 13 (2017), pp. 152-167

[3] World Health Organization (WHO, 2011). The guidelines for drinking waterquality, $4^{\text {th }}$ ed.

[4] A.R. Khalit; Current State of Water Environment in Malaysia (2016) http://www.wepa- 
db.net/pdf/0712forum/paper09.pdf [July 27, 2016]

[5] J.R. De Palma, J.D. Pittard; Body Water-body Weight (2001) http://www.hemodialysisinc.com/articles/bodywater.pdf (Accessed 09 April 2017)

[6] P. Payment, Goals of Water Treatment and Disinfection: Reduction in Morbidity and Mortality, Dlm. Willie O.K. Grabow (pnyt.). Water and Health (2009) 122-133 Encyclopedia of Life Support Systems (EOLSS), United Kingdom.

[7] X.M. Tang, H.L. Zheng, H.K. Teng, Y.J. Sun, J.S. Guo, W.Y. Xie, Q.Q. Yang, W. ChenChemical coagulation process for the removal of heavy metals from water: a review, Desalin. Water Treat., 57 (2016), pp. 1733-1748

[8] O. Kononova, G. Bryuzgina, O. Apchitaeva, Y. KononovIon exchange recovery of chromium (VI) and manganese (II) from aqueous solutions, Arab. J. Chem. (2015), pp. 1-8

[9]X. Du, K. Zhang, B. Xie, J. Zhao, X. Cheng, L. Kai, J. Nie, Z. Wang, G. Li, H. LiangPeroxymonosulfate-assisted electrooxidation/coagulation coupled with ceramic membrane for manganese and phosphorus removal in surface water Chem. Eng. J., 365 (2019), pp. 334-343

[10] B. Al-Rashdi, C. Somerfield, N. HilalHeavy metals removal using adsorption and nanofiltration techniques, Sep. Purif. Rev., 40 (2011), pp. 209-259

[11] C.M. Chew, M.K. Aroua, M.A. Hussain, W.M.Z.W. IsmailPractical performance analysis of an industrial-scale ultrafiltration membrane water treatment plant, J. Taiwan Inst. Chem. Eng., 46 (2015), pp. 132-139

[12]Qianqian Shi, Aimin Li, Qing Zhou, ChendongShuang, Yan Ma; Utilization of wastecation exchange resin to prepare carbon/iron composites for the adsorption of contaminants in water, Journal of Industrial and Engineering Chemistry 20 (2014) 4256-4260.

[13]J. Coates; Interpretation of infrared spectra, a practical approach; R.A. Meyers (Ed.), Encyclopedia of analytical chemistry, John Wiley \& Sons Ltd, Chichester (2000) 1081510837.

[14] E. Apaydın-Varol, A.E. Pütün; Preparation and characterization of pyrolytic chars from different biomass samples, J. Anal. Appl. Pyrolysis, 98 (2012) 29-36,
[15]ÖzgülGerçel, Adnan Özcan, A. SafaÖzcan, H. FerdiGerçel; Preparation of activated carbon from a renewable bio-plant of Euphorbia rigida by $\mathrm{H} 2 \mathrm{SO} 4$ activation and its adsorption behavior in aqueous solutions, Applied Surface Science253 (2007) 4843-4852.

[16]Ali H. Jawad, R.Razuan, Jimmy Nelson Appaturi, Lee D. Wilson; Adsorption and mechanism study for methylene blue dye removal with carbonized watermelon (Citrulluslanatus) rind prepared via one-step liquid phase $\mathrm{H} 2 \mathrm{SO} 4$ activation, Surfaces and Interfaces 16 (2019) 76-84.

[17]Alexander M.Puziy, Olga I. Poddubnaya, Amelia Martínez-Alonso, Alberto CastroMuñiz, Fabian Suárez-García, Juan M.D.Tascón; Oxygen and phosphorus enriched carbons from lignocellulosic material, Carbon45 (2007) 1941-1950.

[18]Nan Zhou, Yifan Wang, Liyang Huang, Jingang Yu' Huanli Chen, Jiajie Tang, FengjuanXu, Xiangyang Lu, Mei-e Zhong, ZhiZhou; In situ modification provided by a novel wet pyrolysis system to enhance surface properties of biochar for lead immobilization, Colloids and Surfaces A: Physicochemical and Engineering Aspects570 (2019) 39-47.

[19] S. Kushwaha, H. Soni, B. Sreedhar, P. Padmaja; Efficient valorisation of palm shell powder to bio-sorbents for copper remediation from aqueous solutions, Journal of Environmental Chemical Engineering 5 (2017) 2480-2487.

[20]N. A. H. MohamadZaidi, L. B. L. Lim, A. Usman; Enhancing adsorption of $\mathrm{Pb}$ (II) from aqueous solution by $\mathrm{NaOH}$ and EDTA modifiedArtocarpusodoratissimus leaves, Journal of Environmental Chemical Engineering, 6 (2018) 7172-7184

[21]Xu P., Zeng G., Huang D., Hu S., Feng C., Lai C., Zhao M., Huang C., Li N., Wei Z, Xie G.; Synthesis of iron oxide nanoparticles and their application in Phanerochaetechrysosporium immobilization for $\mathrm{Pb}(\mathrm{II})$ removal, Colloids Surf A PhysicochemEng Aspects, 419 (2013), pp. 147-155.

[22]Priya Saharan, Ashok K. Sharma, Vinit Kumar, InduKaushal; Multifunctional CNT supported metal doped $\mathrm{MnO}_{2}$ composite for adsorptive removal of anionic dye and thiourea sensing, Materials Chemistry and Physics 221 (2019) 239-249.

[23] T. Hajeeth, K. Vijayalakshmi, T. Gomathi, P.N. Sudha; Removal of $\mathrm{Cu}(\mathrm{II})$ and $\mathrm{Ni}(\mathrm{II})$ using 
cellulose extracted from sisal fiber and cellulose-g-acrylic acid copolymer, Int $\mathrm{J}$ BiolMacromol, 62 (2013), pp. 59-65

[24] Deepak Tiwari, HaripadaBhunia, Pramod K. Bajpai; Adsorptionof $\mathrm{CO}_{2}$ onKOHactivated, Nenrichedcarbonderivedfromureaformaldehydere sin: kinetics, isotherm and thermodynamicstudies, Applied Surface Science, Volume 439, 1 May 2018, Pages 760771.

[25]DivyamJhaa, N.M. Mubarakb, Mohd. BelalHaidera, Rakesh Kumara, M.S. Balathanigaimania, J.N. Sahu; Adsorptive removal of dibenzothiophene from diesel fuel using microwave synthesized carbon nanomaterials, Fuel 244 (2019) 132-139.

[26]Li Wang, Jingyi Wang, Chi He, Wei Lyu, Wenlong Zhang, Wei Yan, Liu Yang; Development of rare earth element doped magnetic biochars with enhanced phosphate adsorption performance, Colloids and Surfaces A 561 (2019) 236-243.

[27]ElhamBoorboorAzimi, AlirezaBadiei, Jahan B. Ghasemi; Efficient removal of malachite green from wastewater by using boron-doped mesoporous carbon nitride, Applied Surface Science 469 (2019) 236-245.

[28]AyyubKhawar, ZaheerAslam, Abdul Zahir, Imran Akbar, Aamir Abbas; Synthesis of Femur extracted hydroxyapatite reinforced nanocomposite and its application for $\mathrm{Pb}(\mathrm{II})$ ions abatement from aqueous phase, International Journal of Biological Macromolecules 122 (2019) 667-676.

[29]Aola Supong, Parimal Chandra Bhomick, Mridushmita Baruah, Chubaakum Pongener, DipakSinha; Adsorptive removal of Bisphenol A by biomass activated carbon and insights into the adsorption mechanism through density functional theory calculations, Sustainable Chemistry and Pharmacy, Volume 13, September 2019, Article 100159.

[30]Soh-Fong Lim \& Agnes Yung Weng Lee; Environ Sci Pollut Res (2015) 22:10144-10158.

[31]Drishti Bhatia, Dipaloy Datta, Abhishek Joshi, Sagar Gupta, Yogesh Gote; Adsorption of isonicotinic acid from aqueous solution using multi-walled carbon nanotubes/Fe3O4, Journal of Molecular Liquids 276 (2019) 163-169 Journal of Molecular Liquids 276 (2019) 163 169.

[32]Yuhao Zhou, Zhe Liu, Arixin Bo, Tana Tana, Huaiyong Zhu; Simultaneous removal of cationic and anionic heavy metal contaminants from electroplating effluent by hydrotalcite adsorbent with disulfide (S2-) intercalation, Journal of Hazardous Materials, Volume 382, 15 January 2020, Article 121111

[33] G. Zhou, J. Luo, C. Liu, L. Chu, J. Crittenden; Efficient heavy metal removal from industrial melting effluent using fixed-bed process based on porous hydrogel adsorbents, Water Res., 131 (2018) (2018), pp. 246-254.

[34] H. Sharififard, Z.H. Shahraki, E. Rezvanpanah, S.H. Rad; A novel natural chitosan/activated carbon/iron bio-nanocomposite: Sonochemical synthesis, characterization, and application for cadmium removal in batch and continuous adsorption process, Bioresour. Technol., 270 (2018), pp. 562-569.

[35] B. Das, N.K. Mondal, R. Bhaumik, P. Roy; Insight into adsorption equilibrium, kinetics and thermodynamics of lead onto alluvial soil, Int. J. Environ. Sci. Technol. (Tehran), 11 (2014), pp. 1101-1114.

[36]Yasser Hannachi, AfifaHafidh, SalwaAyed; Effectiveness of novel xerogelsadsorbents for cadmium uptake from aqueoussolution in batch and column modes: Synthesis, characterization, equilibrium, and mechanismanalysis, Chemical Engineering Research and Design, Volume 143, March 2019, Pages 11-23

[37] Rainwater, F.H. and L.L. Thatcher, 1960. Methods for collection and analysis of water samples.U.S. Geol. Surv.Water Supply. Paper No.1454, U.S.A., p: 301.

[38]Fishman, M.J. and L.C. Friedman, 1985. Methods for determination of inorganic substances in water and fluvial sediments.U.S. Geol. Surv. Book 5, Chapter A1. Open File Report, 85-495, Denver, Colorado, U.S.A.

[39]J. Zhang, S. Chen, H. Zhang, X. Wang; Removal behaviors and mechanisms of hexavalent chromium from aqueous solution by cephalosporin residue and derived chars, Bioresource and Technology., 238 (2017) 484.

[40] Abhay Prakash Rawat, D. P. Singh; Application of biosorbents derived from agrowaste in removal of dyes and heavy metals from aqueous solutions, Ecotoxicology and Environmental Safety 176 (2019) 27-33.

[41] E. Fosso-Kankeu, H. Mittal, F. Waanders, S.S. Ray Thermodynamic properties and adsorption behavior of hydrogel nanocomposites for cadmium removal from mine effluents, J. Ind. Eng. Chem., 48 (2017) 151-161, 
[42]Amal Djelad, Adel Mokhtar, Amine Khelifa, Abdelkader Bengueddach, Mohamed Sassi; Alginate-whey an effective and green adsorbent for crystal violet removal: Kinetic, thermodynamic and mechanism studies, International Journal of Biological Macromolecules 139 (2019) 944-954.
[43]G. Zhou, J. Luo, C. Liu, L. Chu, J. Crittenden; Efficient heavy metal removal from industrial melting effluent using fixed-bed process based on porous hydrogel adsorbents, Water Research., 131 (2018) (2018) 246-254,

الملخص العربى - الم

\title{
تحضير الكربون المنشط من راتنجات التبادل الأيوني وتطبيقه لإزالة المنجنيز من المياه الجوفية البادية
}

\author{
عبد السميع سويلم1 ، يحيي جدامي2 ، احمد الشاهد2 \\ 1- قسم الكيمياء ، كلية العلوم ، جامعة الازهر ، القاهرة ، مصر
}

2- قسم الهيدروجيوكيمياء ، مركز بحوث الصحراء ، المطرية ، القاهرة ، مصر

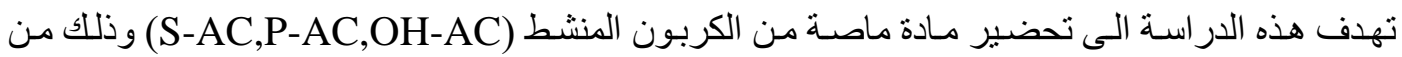

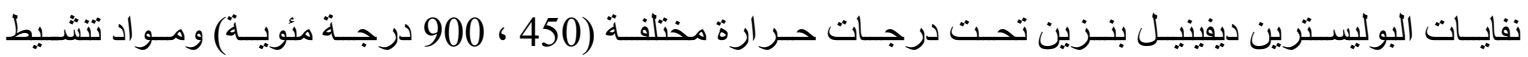
( $\left.{ }_{2} \mathrm{SO}_{4}, \mathrm{H}_{3} \mathrm{PO}_{4}, \mathrm{NaOH}\right)$

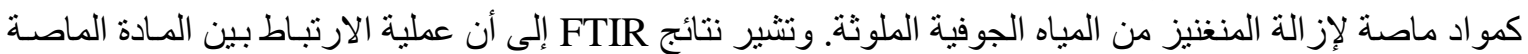

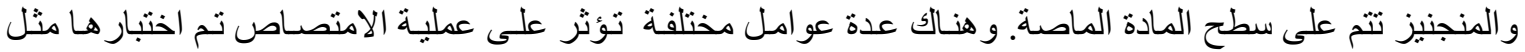

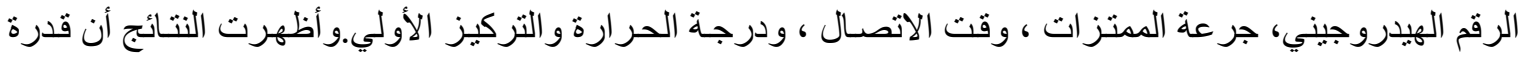

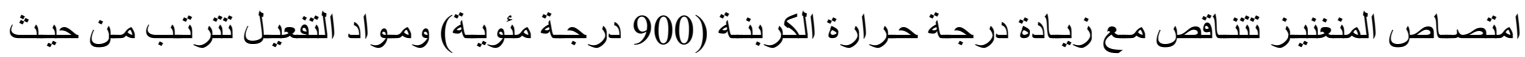
التأثير الى

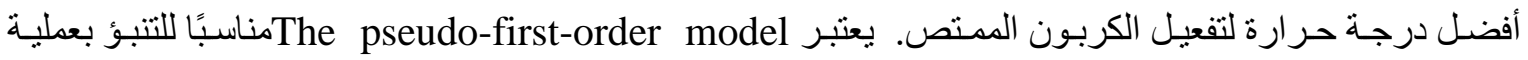

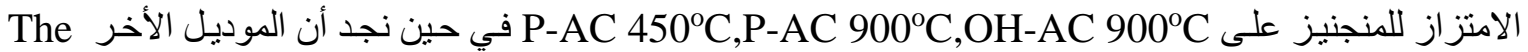

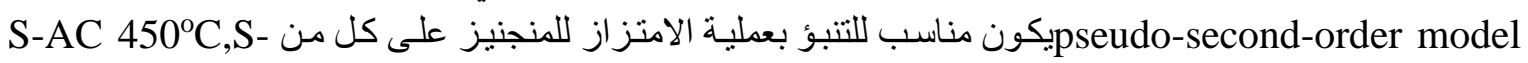
AC 900O C,OH-AC $450^{\circ} \mathrm{C}, \mathrm{OH}-\mathrm{AC} 900^{\circ} \mathrm{C}$

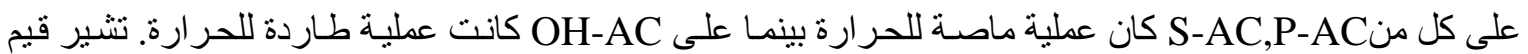

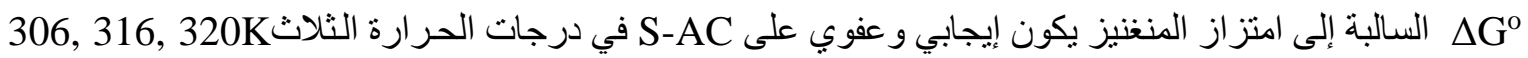

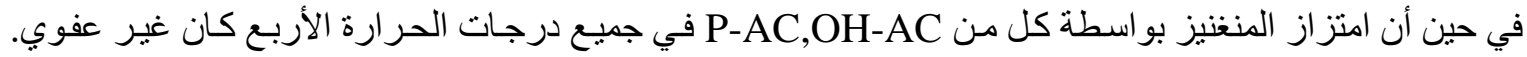

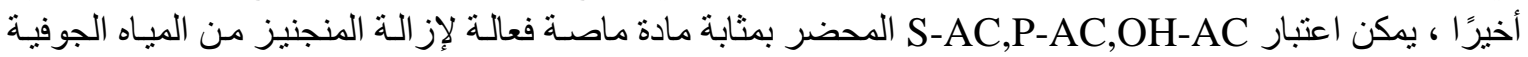

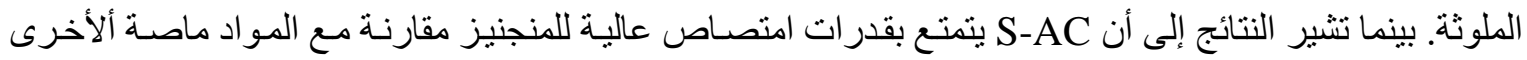
مثل P-AC,OH-AC. لذلك يمكن استخدام S-AC 450C في وحدات معالجة المياه الجوفية الملوثه.
\end{abstract}

